



\section{Analyse beschikbare technieken voor integrale emissiereductie in varkensstallen}

André Aarnink ${ }^{1}$, Jos de Groot ${ }^{2}$ en Marith Booijen ${ }^{1}$

1 Wageningen Livestock Research

2 DLV Advies

Dit onderzoek is uitgevoerd door Wageningen Livestock Research en gesubsidieerd door het ministerie van Landbouw, Natuur en Voedselkwaliteit, in het kader van het Beleidsondersteunend onderzoek thema 'Veilige en duurzame primaire productie' (projectnummer BO-43-111-017-WLR).

Wageningen Livestock Research

Wageningen, november 2021

Rapport 1332 
Aarnink, A.J.A., J. de Groot, M. Booijen, 2021. Analyse beschikbare technieken voor integrale emissiereductie in varkensstallen. Wageningen Livestock Research, Rapport 1332.

\section{Samenvatting NL}

Vanwege de urgentie om stikstofemissies en -depositie terug te dringen, is een goed beeld nodig van de tijdslijn voor implementatie van emissiearme stallen. In dit rapport gaan we in op innovaties in varkensstallen. Daarbij gaat het om stallen die via brongerichte maatregelen of via een combinatie tussen brongericht en end-of-pipe een integrale emissiereductie bewerkstelligen. Dit betekent dat niet alleen de ammoniakemissie moet worden beperkt, maar tevens de emissies van broeikasgassen (vooral methaan), geur en fijnstof. Het gaat hierbij om perspectiefvolle maatregelen die voor de varkenshouders beschikbaar zijn of komen in de komende jaren.

\section{Summary UK}

Due to the urgency to reduce nitrogen emissions and deposition, a good picture of the timeline for implementation of low-emission housing is needed. In this report we discuss innovations in pig houses. This concerns pig houses that achieve an integral emission reduction through source-oriented measures or through a combination between source-oriented and end-of-pipe. This means that not only ammonia emissions should be reduced, but also emissions of greenhouse gases (especially methane), odour and particulate matter. It concerns promising measures that are or will be available for pig farmers in the coming years.

Dit rapport is gratis te downloaden op https://doi.org/10.18174/551114 of op www.wur.nl/livestock-research (onder Wageningen Livestock Research publicaties).

\section{(cc) BY-NC}

Dit werk valt onder een Creative Commons Naamsvermelding-Niet Commercieel 4.0 Internationaallicentie.

(C) Wageningen Livestock Research, onderdeel van Stichting Wageningen Research, 2021

De gebruiker mag het werk kopiëren, verspreiden en doorgeven en afgeleide werken maken. Materiaal van derden waarvan in het werk gebruik is gemaakt en waarop intellectuele eigendomsrechten berusten, mogen niet zonder voorafgaande toestemming van derden gebruikt worden. De gebruiker dient bij het werk de door de maker of de licentiegever aangegeven naam te vermelden, maar niet zodanig dat de indruk gewekt wordt dat zij daarmee instemmen met het werk van de gebruiker of het gebruik van het werk. De gebruiker mag het werk niet voor commerciële doeleinden gebruiken.

Wageningen Livestock Research aanvaardt geen aansprakelijkheid voor eventuele schade voortvloeiend uit het gebruik van de resultaten van dit onderzoek of de toepassing van de adviezen.

Wageningen Livestock Research is NEN-EN-ISO 9001:2015 gecertificeerd.

Op al onze onderzoeksopdrachten zijn de Algemene Voorwaarden van de Animal Sciences Group van toepassing. Deze zijn gedeponeerd bij de Arrondissementsrechtbank Zwolle. 


\section{Inhoud}

Inhoud

3.1 Reeds beschikbare brongerichte maatregelen

3.2 Combinatie van reeds beschikbare brongerichte maatregelen met een nageschakelde techniek

3.3 Kansrijke nieuwe brongerichte maatregelen 


\section{$1 \quad$ Inleiding}

De Nederlandse overheid heeft in maart 2021 de Wet stikstofreductie en natuurverbetering aangenomen, waarin bindende omgevingswaarden zijn vastgesteld om de stikstofdepositie op Natura 2000-gebieden terug te dringen. Dit betreft resultaatverplichtingen voor 2025, 2030 en 2035. In die jaren moeten respectievelijk tenminste $40 \%, 50 \%$ en $74 \%$ van de hectares met stikstofgevoelige natuur in Natura 2000-gebieden onder de kritische depositiewaarden (KDW) worden gebracht. Wat dit precies betekent voor de reductie van ammoniak moet nog nader worden onderzocht. Effectieve reductie van de stikstofdepositie zal zowel generieke als gebiedsgerichte aanpakken moeten combineren en de (kosten-)effectiviteit van maatregelen zal sterk afhankelijk zijn van de locatie ten opzichte van de kwetsbare Natura 2000-gebieden (TNO, Oktober 2019). Om stikstofreductie te realiseren is een heel pakket aan stikstofreducerende bronmaatregelen ontwikkeld. Ook de veehouderij zal hier haar bijdrage moeten leveren. Vanuit de veehouderij emitteert stikstof vooral in de vorm van ammoniak $\left(\mathrm{NH}_{3}\right)$. Om implementatie van brongerichte stikstofreductiemaatregelen te stimuleren is sinds 2020 de Subsidieregeling brongerichte verduurzaming stal- en managementmaatregelen (Sbv) van kracht. Deze regeling biedt ondersteuning aan innovaties en eerste investeringen in nieuwe staltechnieken. In de brief van 24 april 2020 is de Tweede Kamer geïnformeerd over de structurele aanpak van stikstof. Ten aanzien van 'stalmaatregelen' is aangegeven dat uiterlijk eind 2023 per diergroep aangescherpte emissienormen voor ammoniak voor nieuwe stallen en geplande renovaties worden gesteld. Deze eisen moeten uiterlijk in 2025 voor alle relevante diergroepen zijn ingevoerd. Voor bestaande stallen moet dan een nader te bepalen overgangsperiode gaan gelden, waarbij rekening wordt gehouden met de mogelijkheden van individuele veehouders.

Vanwege de urgentie om stikstofemissies en -depositie terug te dringen, is een goed beeld nodig van de tijdslijn voor implementatie van emissiearme stallen. In dit rapport gaan we in op innovaties in varkensstallen. Daarbij gaat het om stallen die via brongerichte maatregelen of via een combinatie tussen brongericht en end-of-pipe een integrale emissiereductie bewerkstelligen. Dit betekent dat niet alleen de ammoniakemissie moet worden beperkt, maar tevens de emissies van broeikasgassen (vooral methaan), geur en fijnstof. Het gaat hierbij om perspectiefvolle maatregelen die voor de varkenshouders beschikbaar zijn of komen in de komende jaren. Het doel van dit kennisdocument is inzicht te geven in de potentiele stadia van ontwikkeling en de mogelijke implementatie van de innovatieve varkensstallen per 2021, 2023 en 2025 aan de hand van hierover gestelde vragen van de ministeries LNV en I\&W. Daarnaast heeft het tot doel te reflecteren op de betrouwbaarheid van de technieken, dit naar aanleiding van de uitkomsten uit de CDM/CBS analyse waarin wordt geconcludeerd dat emissiearme technieken in de praktijk waarschijnlijk meer ammoniak emitteren dan de emissiefactoren aangeven (van Bruggen \& Geertjes, 2019; CDM, 2020)

Dit rapport is een vervolg op het rapport "Brongerichte maatregelen voor beperking emissies uit bestaande varkensstallen", uit 2019 (Aarnink et al., 2019). Er zijn een paar verschillen met voornoemde rapportage:

- $\quad$ Dit rapport geeft een update van de beschikbare innovaties, mede op basis van de verschillende innovatieve systemen die voor subsidie zijn aangeboden in de Sbv-regeling.

- $\quad$ Dit rapport geeft een update van de verwachte emissiereducties van de verschillende emissiearme systemen op basis van de huidige stand van het onderzoek.

- $\quad$ Bij de selectie van systemen is uitgegaan van een minimale ammoniakreductie zoals die is gesteld vanuit de Sbv-regeling, dit betekent minimaal 70\% reductie bij vleesvarkens, gespeende biggen en kraamzeugen en minimaal $60 \%$ reductie bij dragende zeugen, ten opzichte van een stal zonder emissiereducerende maatregelen. Deze minimale ammoniakreducties zeggen echter niets over toekomstig vast te stellen normen voor ammoniak.

In hoofdstuk 2 worden de vragen weergegeven die gesteld zijn door de Ministeries van LNV en I\&W. Deze worden in hoofdstuk 3 beantwoord. In hoofdstuk 4 wordt een discussie gevoerd over de maatregelen die het meeste perspectief bieden voor een integrale reductie van emissies en in welke stallen deze toepasbaar zijn. In hoofdstuk 5 tenslotte worden de samenvattende antwoorden gegeven op de gestelde vragen. 


\section{Te beantwoorden vragen}

Om een beeld te krijgen van de mogelijkheden en implementatie van brongerichte maatregelen om de ammoniak en andere emissies te verminderen, zullen de volgende vragen worden beantwoord:

1. Welke bestaande systemen zijn beschikbaar voor een varkenshouder voor directe implementatie van een integrale brongerichte aanpak van emissies (ammoniak, methaan, geur, fijnstof/endotoxinen), welke leiden tot een vermindering van emissies naar de leefomgeving en een verbetering van het stalklimaat?

2. Welke nageschakelde technieken zijn er en welke emissiereducties zijn hiermee te behalen?

3. Welke brongerichte maatregelen kunnen gecombineerd worden met een nageschakelde techniek en welke emissiereducties zijn hiermee te behalen?

4. Welke nieuwe brongerichte maatregelen zijn in ontwikkeling en welke bedrijven bieden dit systeem aan?

5. In welke fase van de innovatiecyclus bevindt dit systeem zich en wanneer is het klaar voor implementatie?

6. Wat zijn de potentiële emissiereducties die behaald kunnen worden en welk effect heeft het op de kwaliteit van de stallucht?

7. Wat zijn de investerings- en jaarkosten voor deze systemen?

8. Wat is er nodig aan (nieuwe) kennis om een besluit te kunnen nemen over aanscherping van emissie-eisen voor varkens in nieuwe en bestaande stallen?

9. CDM/CBS analyse geeft aan dat er bij veel technieken vragen zijn over de betrouwbaarheid in de praktijk van het rendement. Welke technieken scoren hier beter?

Bovenstaande vragen worden in hoofdstuk 3 beantwoord.

Opmerkingen vooraf:

- De volgende omschrijving wordt gehanteerd voor brongerichte maatregelen: maatregelen die niet alleen de emissies naar de omgeving (buiten de stal) verminderen, maar tevens de concentraties in de stal verlagen door een reductie van de emissies bij de bron, waardoor een betere luchtkwaliteit ontstaat voor mens en dier in de stal. Voorgaande geldt ook voor systemen die de lucht in de stal zodanig reinigen dat de luchtkwaliteit in de omgeving van het dier (en van de dierverzorger) wordt verbeterd.

- Ammoniak, geur en broeikasgassen (vooral methaan) komen voor een belangrijk deel vrij uit mengmest in de mestput. Fijnstof daarentegen komt vooral vrij via opgedroogde feces op de vloer en huidschilfers van de varkens. Fijnstofreductie bij de bron zal daarom vrijwel altijd aanvullende maatregelen vergen t.o.v. de maatregelen gericht op de emissies uit mengmest.

- We beperken ons in dit document tot de emissies uit de stal. Natuurlijk moet voorkomen worden dat emissies die in stal worden gereduceerd buiten de stal alsnog emitteren. Voor ammoniak en geur geldt dat afdekken van buitenopslagen en emissiearm aanwenden de emissies verder in de keten belangrijk kunnen beperken. Voor methaan geldt dit in mindere mate. Langdurige opslag in een buitenopslag kan significante methaanemissies geven, alhoewel daar nog niet veel over bekend is. Wel is het zo dat de gemiddelde temperatuur van de mest in een buitenopslag beduidend lager is dan bij opslag in de stal. Onderzoek is nodig om dit verschil in methaanemissie tussen binnen- en buitenopslag vast te stellen. Het beste is om de mest snel verder te brengen in de keten (aanwenden of verwerken).

- Benoemde investeringskosten zijn de kosten voor het bouwen van een systeem in een nieuwe stal. Het betreft de meerkosten ten opzichte van de standaardstal in KWIN 20/21 met een luchtwasser. Omdat het vaak bouwkundige voorzieningen betreft met soms een investering in een techniek buiten de stal zijn de investeringskosten veelal hoger dan de KWIN 20/21 standaardstal met luchtwasser.

- Benoemde jaarkosten zijn de kosten voor afschrijving, rente, onderhoud en variabele exploitatiekosten zoals toevoegmiddelen, afvoer van de toevoegmiddelen, etc. Bij veel 
brongerichte systemen waar geen bewegende delen of toevoegmiddelen nodig zijn zullen de totale jaarkosten lager zijn ten opzichte van een luchtwasser.

- Investerings- en jaarkosten van emissie-reducerende stalsystemen zijn vergeleken met de kosten van een stal met een gecombineerd luchtwassysteem (combi-wasser) zonder brongerichte maatregelen. De kosten van de combi-wasser zijn terug te vinden in Bijlage 1.

- De betrouwbaarheid/robuustheid van een systeem is gebaseerd op de eenvoud van het systeem bij het installeren en bouwen, benodigd onderhoud aan het systeem, benodigde managementaandacht (toevoegmiddelen/rapportage/controle werking/mate van automatisering) en benodigde kosten voor onderhoud en toevoegmiddelen (hoe hoger hoe minder betrouwbaar/robuust). Hierbij is als uitgangspunt genomen dat de ondernemer goed ondernemerschap toont voor het gekozen systeem. 


\section{Antwoord op de vragen}

\subsection{Reeds beschikbare brongerichte matregelen}

In deze paragraaf wordt antwoord gegeven op vraag 1:

- Welke bestaande systemen zijn beschikbaar voor een varkenshouder voor directe implementatie van een integrale brongerichte aanpak van emissies (ammoniak, methaan, geur, fijnstof en endotoxinen), welke leiden tot een vermindering van emissies naar de leefomgeving en een verbetering van het stalklimaat?

Deze vraag wordt in Tabel 1 beantwoord. Deze tabel bevat systemen die al opgenomen zijn in de Ravlijst. In Tabel 1 zijn alleen die systemen opgenomen die via brongerichte maatregelen voldoen aan de minimale eis van ammoniakreductie binnen de Sbv-regeling; dit betekent een minimale ammoniakreductie van $70 \%$ bij gespeende biggen, kraamzeugen en vleesvarkens en van $60 \%$ bij dragende zeugen. Voorgaande betekent niet dat dit de toekomstige normen zullen worden voor ammoniak. Dat besluit moet nog worden genomen. De reducties zijn berekend door de ammoniakemissiefactor van dit systeem in de Rav-lijst (www.rvo.nl) te vergelijken met de emissiefactor voor overige huisvestingssystemen (systemen van de Rav-lijst met D _._.100 code). Naast ammoniak, zijn ook reductiepercentages opgenomen voor geur, methaan en fijnstof. Voor de reducties van ammoniak is uitgegaan van de ammoniakemissiefactoren zoals die opgenomen zijn in de Rav-lijst. Voor geur en fijnstof is in principe uitgegaan van de emissiefactoren zoals opgenomen in de lijst van InfoMil (www.infomil.nl) waarbij de geuremissiefactoren van de Regeling geurhinder en veehouderij (Rgv) en de emissiefactoren voor fijnstof zijn weergegeven per diercategorie, tenzij er redenen waren om af te wijken van deze lijst. In sommige gevallen was daar reden toe aangezien in de Rav-lijst vrijwel geen onderscheid is gemaakt in deze emissies, terwijl op basis van voortschrijdend inzicht daar wel reden toe is en ook min of meer noodzakelijk om deze getallen in overeenstemming te brengen met de inschattingen van de reducties voor de nieuwe systemen. Bij de inschatting van de fijnstofreductie zijn we er als benadering vanuit gegaan dat de endotoxine-emissie evenveel wordt gereduceerd als fijnstof. Dit is te rechtvaardigen door het feit dat endotoxines onderdeel vormen van het fijnstof, echter de verschillende fijnstofbronnen bevatten verschillende gehalten aan endotoxinen. Gedroogde mest bevat bijvoorbeeld veel meer endotoxine dan voer (Winkel et al., 2014). Als een reductiemaatregel de ene fijnstofbron sterker reduceert dan een andere zal dat effect hebben op de mate van reductie van endotoxine ten opzichte van de reductie van fijnstof. De inschattingen van de emissiereducties voor methaan zijn gebaseerd op kennis vanuit reeds uitgevoerde metingen en kennis van de processen die zorgen voor de vorming van methaan en de factoren die van invloed zijn op deze processen.

De systemen in Tabel 1 kunnen eventueel gecombineerd worden met nageschakelde technieken. Nageschakelde technieken in de Rav-lijst zijn chemische, biologische en gecombineerde luchtwassystemen en biofilters. De reducties die bereikt worden met deze systemen zijn aanvullend opgenomen aan het eind van Tabel 1.

De ammoniakemissiefactor voor de combinatie met een luchtwasser kan worden berekend met de formules in eindnoot 3 van de Rav-lijst: efc $=0,01 \times(100-\mathrm{rpl}) \times$ efa (efc en efa zijn daarbij de emissiefactoren van de combinatie respectievelijk van het andere emissiearme systeem; rpl geeft het reductiepercentage van de luchtwasser weer). Indien het reductiepercentage van het andere huisvestingssysteem evenwel hoger is dan 70 (efa < 0,3efo, waarbij efo de emissiefactor van overige huisvestingssystemen van de betreffende diercategorie is), dan geldt evenwel: efc $=0,01 \times(100-\mathrm{rpl})$ $x$, 3efo. Voor de laatste formule geldt dat de gecombineerde reductie niet lager kan zijn dan de reductie die wordt behaald met het andere huisvestingssysteem. 
Voor de andere emissies stellen we de volgende benadering voor om het gecombineerde effect te berekenen:

- Geur: dezelfde rekenwijze als voor ammoniak minus $10 \%$ aftrek van het berekende reductiepercentage. Als de berekende gecombineerde reductie op basis van de hierboven weergegeven rekenwijze voor ammoniak b.v. $60 \%$ is, dan wordt dit na $10 \%$ aftrek: $60 \% * 0,90=$ $54 \%$. Deze aftrek achten wij noodzakelijk omdat geur uit veel verschillende componenten bestaat. Het kan zijn dat bepaalde geurcomponenten niet worden gereduceerd door de bronmaatregelen en ook niet door de nageschakelde techniek. De berekende geurreductie van de gecombineerde maatregelen kan niet lager zijn dan de geurreductie van de enkelvoudige maatregelen.

- Methaan: dezelfde rekenwijze als voor ammoniak. Hierbij dient opgemerkt te worden dat methaan niet wordt gereduceerd in de huidig beschikbare luchtwassystemen.

- Fijnstof/endotoxine: dezelfde rekenwijze als voor ammoniak.

Uit Tabel 1 kan het volgende worden geconcludeerd:

- Voor gespeende biggen zijn verschillende brongerichte systemen beschikbaar die een ammoniakreductie geven van $70 \%$ of meer ten opzichte van een stal zonder maatregelen. Behalve voor de systemen met spoelgoten, geven deze systemen ook een geurreductie van naar verwachting $30-50 \%$. De methaanemissie wordt naar verwachting met $30-90 \%$ gereduceerd. Deze systemen hebben naar verwachting geen effect op de emissie van fijnstof. Hiervoor is een additionele maatregel nodig.

- Bij kraamzeugen zijn een drietal systemen beschikbaar die een ammoniakreductie geven van tenminste $70 \%$. Ze geven naar verwachting ook een significante emissiereductie van methaan (40 $-80 \%$ ). Voor geur en fijnstof worden geen reducties verwacht bij deze systemen.

- Bij dragende zeugen is één systeem opgenomen in de Rav-lijst die meer dan $60 \%$ ammoniakreductie behaald en voor vleesvarkens is één systeem beschikbaar met een ammoniakreductie van meer dan 70\%. Deze systemen geven, naar verwachting, tevens een significante reductie van geur $(40-50 \%)$ en methaan $(60-80 \%)$. Voor fijnstofreductie is een additionele maatregel nodig.

- De brongerichte maatregelen worden gekenmerkt door één of een combinatie van onderstaande kenmerken:

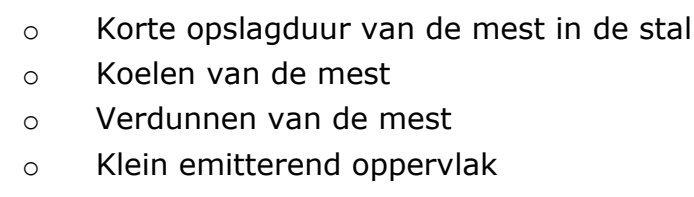

- De investeringskosten zijn voor de meeste systemen hoger dan voor de standaard stal met luchtwasser. De jaarkosten (totaalkosten op jaarbasis) variëren van veel lager tot veel hogeren zijn opgebouwd uit de kosten voor afschrijving, rente, onderhoud en variabele exploitatiekosten zoals toevoegmiddelen, afvoer van de toevoegmiddelen, etc. Systemen met bewegende delen kunnen goedkoper zijn als deze robuust zijn en weinig slijtage vertonen (spoelsystemen bijv.). Bij mestschuiven en soortgelijke technieken kan het onderhoud wel hoger zijn. Dit zal een van de zaken zijn die bij het toepassen van het systeem in de praktijk moet blijken. Ook de noodzaak van toevoegmiddelen voor het behalen van de benodigde reductiepercentages zal de jaarkosten negatief beïnvloeden. Bij sommige systemen zal er een reductie zijn van mestkosten, maar vaak is dit ook bij de standaard stal toe te passen. Daarnaast kan er op zeugenbedrijven een besparing zijn op energiekosten bij bijvoorbeeld koelsystemen.

- Door brongerichte reductiesystemen te combineren met een luchtwasser kunnen door de wasser vooral de emissies van ammoniak, geur en fijnstof aanvullend worden gereduceerd. Reductiepercentages kunnen berekend worden aan de hand van eerder genoemde formules. Een voorbeeld hiervan is de combinatie van mestopvang in water met een mestafvoersysteem voor gespeende biggen in combinatie met een chemisch luchtwassysteem met $95 \%$ ammoniakreductie. Hiermee worden gecombineerde reducties verwacht van $98 \%$ ammoniak, $46 \%$ geur, 30\% methaan en $35 \%$ fijnstof. De combinatie van schuiven in de mestgoot voor kraamzeugen met een biologisch luchtwassysteem met $85 \%$ ammoniakreductie en $75 \%$ fijnstofreductie geeft naar verwachting gecombineerde reducties van 95\% ammoniak, 55\% geur, 80\% methaan en $75 \%$ fijnstof. Voor een combi-luchtwasser kunnen vergelijkbare voorbeelden worden gegeven. De combinatie van deze luchtwasser op een vleesvarkensstal met hokken met mestkelders met water- en mestkanaal etc. 
geeft naar verwachting gecombineerde reducties van 97\% ammoniak, 65\% geur, 80\% methaan en $80 \%$ fijnstof. De combi-luchtwasser op een stal voor dragende zeugen gecombineerd met hokken met kelders met water- en mestkanaal etc. geeft naar verwachting gecombineerde reducties van $96 \%$ ammoniak, $60 \%$ geur, $60 \%$ methaan en $80 \%$ fijnstof. 


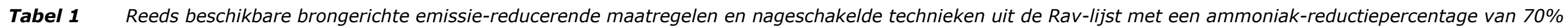
en hoger voor gespeende biggen, kraamzeugen en vleesvarkens, en van 60\% en hoger voor dragende zeugen (ammoniakreductie-eisen in Sbv-regeling). De tabel geeft een inschatting van de emissiereducties en het effect op de luchtkwaliteit. Tevens is aangegeven voor welke categorieën varkens deze initiatieven geschikt zijn, wat de investerings- en jaarkosten zijn, en is een score gegeven voor de betrouwbaarheid/robuustheid van het systeem. Opmerking: de aangegeven reducties van ammoniak, geur en fijnstof zijn afkomstig uit de Rav-lijst; voor geur en fijnstof is hier in sommige gevallen van afgeweken, vanwege nieuwe inzichten. Voor methaan zijn geen cijfers opgenomen in de Rav-lijst, daarom zijn indicatieve reducties weergegeven, afgerond op 5\%, en vooral gebaseerd op expertkennis.

\begin{tabular}{|c|c|c|c|c|c|c|c|c|c|c|}
\hline \multirow[t]{2}{*}{ Systeem } & \multirow[t]{2}{*}{ Rav code } & \multirow{2}{*}{$\begin{array}{l}\text { NH3 } \\
(\%)\end{array}$} & \multirow{2}{*}{$\begin{array}{l}\text { Geur } \\
(\%)\end{array}$} & \multirow{2}{*}{$\begin{array}{c}\text { Methaan } \\
(\%)\end{array}$} & \multirow{2}{*}{$\begin{array}{c}\text { Fijnstof } \\
(\%)\end{array}$} & \multirow{2}{*}{$\begin{array}{l}\text { Luchtkwali } \\
\text { teit stal }^{1}\end{array}$} & \multicolumn{2}{|c|}{ Kosten ${ }^{2}$} & \multirow{2}{*}{$\begin{array}{c}\text { Betrouwbaarheid } \\
\text { / robuustheid } \\
\text { systeem }{ }^{3}\end{array}$} & \multirow[t]{2}{*}{ Opmerkingen } \\
\hline & & & & & & & Investering & Jaarlijks & & \\
\hline \multicolumn{11}{|l|}{ Gespeende biggen } \\
\hline $\begin{array}{l}\text { Vlakke gecoate keldervloer met } \\
\text { tandheugelschuifsysteem }\end{array}$ & D 1.1 .1 & $71 \%$ & $50 \%^{4}$ & $90 \%$ & $0 \%$ & ++ & ++ & + & 4 & $\begin{array}{l}\text { Installatie bouw ingewikkeld en } \\
\text { onderhoud vergt aandacht }\end{array}$ \\
\hline $\begin{array}{l}\text { Mestopvang in water in combinatie met een } \\
\text { mestafvoersysteem }\end{array}$ & D 1.1 .3 & $78 \%$ & $30 \%$ & $30 \%$ & $0 \%$ & ++ & ++ & + & 5 & Simpel bouwen en weinig management \\
\hline $\begin{array}{l}\text { Mestopvang in en spoelen met aangezuurde vloeistof } \\
\text { (volledig roostervloer) }\end{array}$ & D 1.1 .6 & $74 \%$ & $0 \%$ & $80 \%$ & $0 \%$ & + & ++ & 0 & 3 & $\begin{array}{l}\text { Pompen en vloeistof maken en } \\
\text { zuurgebruik }\end{array}$ \\
\hline Koeldeksysteem (150\% koeloppervlak) & D 1.1 .11 & $75 \%$ & $30 \%$ & $50 \%$ & $0 \%$ & ++ & + & - & 5 & $\begin{array}{l}\text { Indien systeem goed geïnstalleerd } \\
\text { werkt het prima }\end{array}$ \\
\hline Opfokhok met schuine putwand met spoelgoten & D 1.1 .12 & $70-75 \%$ & $0 \%$ & $80 \%$ & $0 \%$ & + & - & -- & 5 & $\begin{array}{l}\text { NH3-reductie afhankelijk van } \\
\text { emitterend opp. en groepsgrootte }\end{array}$ \\
\hline $\begin{array}{l}\text { Hok met conditionering van de ligvloertemperatuur, } \\
\text { mestkelders met water- en mestkanaal, mestkanaal }\end{array}$ & D 1.1 .18 & $70 \%$ & $50 \%^{4}$ & $80 \%$ & $0 \%$ & ++ & + & 0 & 3 & $\begin{array}{l}\text { Systeem met veel onderdelen om } \\
\text { emissie te reduceren }\end{array}$ \\
\hline
\end{tabular}

met metaln diekant roostervloer met me

beide kanalen voorzien van een pan met

watervulsysteem, dagelijkse mestafvoer uit het

mestkanaal en

een emitterend oppervlak van maximaal 0,062 m2

per big 


\begin{tabular}{|c|c|c|c|c|c|c|c|c|c|c|}
\hline \multirow[t]{2}{*}{ Systeem } & \multirow[t]{2}{*}{ Rav code } & \multirow[t]{2}{*}{$\begin{array}{l}\mathrm{NH3} \\
(\%)\end{array}$} & \multirow[t]{2}{*}{$\begin{array}{l}\text { Geur } \\
(\%)\end{array}$} & \multirow[t]{2}{*}{$\begin{array}{l}\text { Methaan } \\
(\%)\end{array}$} & \multirow[t]{2}{*}{$\begin{array}{l}\text { Fijnstof } \\
(\%)\end{array}$} & \multirow[t]{2}{*}{$\begin{array}{l}\text { Luchtkwali } \\
\text { teit stal }\end{array}$} & Koste & & \multirow[t]{2}{*}{$\begin{array}{l}\text { Betrouwbaarheid } \\
\text { / robuustheid } \\
\text { systeem }{ }^{3}\end{array}$} & \multirow[t]{2}{*}{ Opmerkingen } \\
\hline & & & & & & & Investering & Jaarlijks & & \\
\hline \multicolumn{11}{|l|}{ Kraamzeugen } \\
\hline Schuiven in mestgoot & D 1.2 .9 & $70 \%$ & $30 \%^{4}$ & $80 \%$ & $0 \%$ & + & ++ & ++ & 3 & $\begin{array}{l}\text { Goede inbouw lastig en veel draaiende } \\
\text { onderdelen in mest }\end{array}$ \\
\hline Koeldeksysteem (150\% koeloppervlak) & D 1.2 .12 & $71 \%$ & $0 \%$ & $40 \%$ & $0 \%$ & + & + & 0 & 5 & $\begin{array}{l}\text { Indien systeem goed geïnstalleerd } \\
\text { werkt het prima; energiebesparing bij } \\
\text { toepassing warmtepomp }\end{array}$ \\
\hline $\begin{array}{l}\text { Mestpan met mestkanaal met koelsysteem en } \\
\text { waterkanaal onder het kraamhok }\end{array}$ & D 1.2 .20 & $84 \%$ & $30 \%^{4}$ & $80 \%$ & $0 \%$ & + & ++ & ++ & 5 & $\begin{array}{l}\text { Indien systeem goed geïnstalleerd } \\
\text { werkt het prima; energiebesparing bij } \\
\text { toepassing warmtepomp }\end{array}$ \\
\hline
\end{tabular}

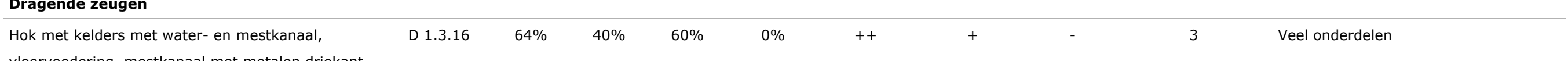

vloervoedering, mestkanaal met metalen driekant

roostervloer met mestspleet, mest- en watergoot met

schuine puntwanden, koelsysteem en watervul-

/spoelsysteem in mestgoot, dagelijkse mestafvoer en

een emitterend oppervlak van maximaal 0,3 $\mathrm{m} 2$ per

varken (BWL 2019.03)

\section{Vleesvarkens}

Hok met mestkelders met water- en mestkanaal,

$74 \%$

$50 \%$

$80 \%$

$0 \%$

$++$

mestkanaal met metalen driekant roostervloer,

mestgoot met schuine putwanden, koelsysteem en

watervul-/spoelsysteem, dagelijkse mestafvoer en

een emitterend mestoppervlak van maximaal $0,08 \mathrm{~m}^{2}$

per varken 


\begin{tabular}{|c|c|c|c|c|c|c|c|c|c|c|}
\hline \multirow[t]{2}{*}{ Systeem } & \multirow[t]{2}{*}{ Rav code } & \multirow[t]{2}{*}{$\begin{array}{l}\text { NH3 } \\
(\%)\end{array}$} & \multirow[t]{2}{*}{$\begin{array}{l}\text { Geur } \\
(\%)\end{array}$} & \multirow[t]{2}{*}{$\begin{array}{c}\text { Methaan } \\
(\%)\end{array}$} & \multirow[t]{2}{*}{$\begin{array}{l}\text { Fijnstof } \\
(\%)\end{array}$} & \multirow[t]{2}{*}{$\begin{array}{l}\text { Luchtkwali } \\
\text { teit stal }^{1}\end{array}$} & Koste & & \multirow[t]{2}{*}{$\begin{array}{l}\text { Betrouwbaarheid } \\
\text { / robuustheid } \\
\text { systeem }^{3}\end{array}$} & \multirow[t]{2}{*}{ Opmerkingen } \\
\hline & & & & & & & Investering & Jaarlijks & & \\
\hline Chemisch luchtwassysteem & & $70-95 \%$ & $30 \%$ & $0 \%$ & $35 \%$ & 0 & - & - & 4 & $\begin{array}{l}\text { Onderhoud en controle nodig; met zuur } \\
\text { emissie te sturen }\end{array}$ \\
\hline Gecombineerd luchtwassysteem & & $70-90 \%$ & $30-45 \%$ & $0 \%$ & $80 \%$ & 0 & 0 & 0 & 3 & $\begin{array}{l}\text { Onderhoud en controle nodig; door } \\
\text { bacteriële werking wat minder snel bij } \\
\text { te sturen, vraagt meer management }\end{array}$ \\
\hline Biofilter & & $70 \%$ & $45 \%$ & $0 \%$ & $80 \%$ & 0 & 0 & 0 & 3 & \\
\hline
\end{tabular}

1) 0 = geen effect; +/- = effect onbekend; + = gematigd positief; ++ = positief; +++ = zeer positief

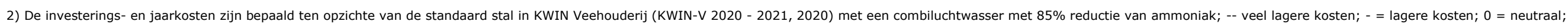
$+=$ hogere kosten $;++=$ veel hogere kosten

3) Schaal van $1 \mathrm{t} / \mathrm{m} 5$, waarin $1=$ systeem is onbetrouwbaar/ niet robuust en $5=$ systeem is betrouwbaar/ robuust

4) Afgeweken van de Rav-lijst 


\subsection{Combinatie van reeds beschikbare brongerichte maatregelen met een nageschakelde techniek}

In deze paragraaf wordt antwoord gegeven op vraag 2:

- Welke brongerichte maatregelen kunnen gecombineerd worden met een nageschakelde techniek en welke emissiereducties zijn hiermee te behalen?

In deze paragraaf zijn de systemen opgenomen uit de Rav-lijst die op zichzelf niet voldoen aan de vereiste ammoniakreductie volgens de Sbv-regeling (70\% voor gespeende biggen, kraamzeugen en vleesvarkens en $60 \%$ voor dragende zeugen), maar wel perspectief kunnen bieden in combinatie met een luchtwasser. Sommige brongerichte maatregelen kunnen ook met andere brongerichte maatregelen worden gecombineerd. De perspectiefvolle combinaties worden in nieuwe stalsystemen al toegepast om maximale emissiereducties te behalen. Deze innovaties zijn terug te vinden in par. 3.3. In Tabel 2 worden de ammoniakemissies weergegeven zoals die zijn vermeld in de Rav-lijst. De emissiefactor voor de combinatie met een luchtwasser kan berekend worden met de formule zoals weergegeven in par. 3.1 voor ammoniak.

Naast ammoniak, zijn ook reductiepercentages opgenomen voor geur, methaan en fijnstof. Net als voor de systemen die vermeld zijn in par. 3.1 is voor de inschatting van de reducties van geur en fijnstof in principe uitgegaan van de emissiefactoren zoals opgenomen in de Rav-lijst, tenzij er redenen waren om daarvan af te wijken. In sommige gevallen was daar reden toe aangezien in de Rav-lijst vrijwel geen onderscheid is gemaakt in deze emissies, terwijl op basis van voortschrijdend inzicht daar wel reden toe was en ook min of meer noodzakelijk om deze getallen in overeenstemming te brengen met de inschattingen van de reducties voor de nieuwe systemen. Bij de inschatting van de fijnstofreductie zijn we er gemakshalve vanuit gegaan dat de endotoxine-emissie evenveel wordt gereduceerd als fijnstof. De inschattingen van de emissiereducties voor methaan zijn gebaseerd op kennis van de processen die zorgen voor de vorming van methaan en de factoren die van invloed zijn op deze processen. Om het gecombineerde effect te berekenen van bronmaatregelen en nageschakelde technieken op de emissiereducties van geur, methaan en fijnstof/endotoxine wordt dezelfde rekenwijze voorgesteld als weergegeven in par. 3.1.

Uit Tabel 2 kan het volgende worden geconcludeerd:

- De brongerichte maatregelen in Tabel 2 hebben, aanvullend op het effect van de luchtwasser, vooral een effect op de methaanemissie. Dit geldt als de mest kortdurend in de stal wordt opgeslagen. De bronmaatregelen in Tabel 2 laten geen of slechts een gering effect op de geur- en fijnstofemissie zien. De volgende systemen hebben naar verwachting wel een significant effect op de geuremissie:

- Schuiven onder de roostervloer met dagelijkse mestverwijdering

- Mestbanden onder de roostervloer met dagelijkse mestverwijdering

- Ondiepe mestkanalen met water- en mestkanaal bij gespeende biggen

- Rondloopstal met strobed voor dragende zeugen

- Alle vermelde systemen bij vleesvarkens geven naar verwachting enige geurreductie ( $22 \%$ volgens de Rav-lijst)

- Het mestbandsysteem geeft naar verwachting de hoogste geurreductie $(70 \%$; gebaseerd op metingen)

- De investeringskosten zijn voor de meeste brongerichte emissie-reducerende maatregelen hoger dan voor de standaard stal met luchtwasser. De jaarkosten (totaalkosten op jaarbasis) zijn in veel gevallen vergelijkbaar of zelfs lager dan voor de referentiestal, behalve voor de gespeende biggen. 


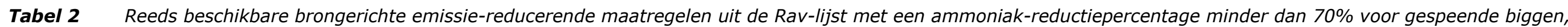
kraamzeugen en vleesvarkens en minder dan 60\% voor dragende zeugen (ammoniakreductie-eisen in Sbv-regeling). Deze maatregelen zouden in combinatie met een nageschakelde techniek wel aan de vereiste ammoniakreducties kunnen voldoen. Voor berekening van het gecombineerde effect (bronmaatregel en end-ofpipe maatregel) zie par. 3.1. De tabel geeft een inschatting van de emissiereducties en het effect op de luchtkwaliteit. Opmerking: de aangegeven reducties van ammoniak, geur en fijnstof zijn afkomstig uit de Rav-lijst; voor geur en fijnstof is hier in sommige gevallen van afgeweken, vanwege nieuwe inzichten. Voor methaan zijn geen cijfers opgenomen in de Rav-lijst, daarom zijn indicatieve reducties weergegeven, afgerond op $5 \%$, en vooral gebaseerd op expertkennis.

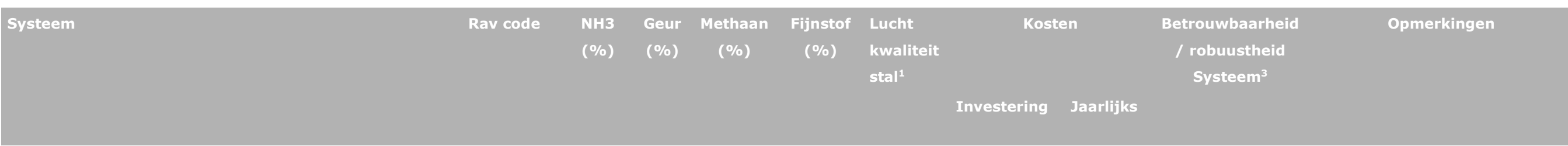

\section{Gespeende biggen}

Spoelgotensysteem met dunne mest en gedeeltelijk roostervloer

Ondiepe mestkelders met water- en mestkanaal

D 1.1 .2

$65 \%$

$0 \% \quad 80 \%$

D 1.1 .4

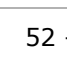

$30 \% \quad 70 \%$

$0 \%$

$+$

$+$

$+$

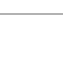

$62 \%$

Halfrooster met verkleind mestoppervlak (max. 60\%

D 1.1 .5

$43 \%$

D 1.1 .7

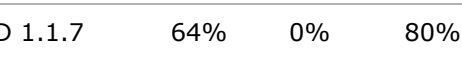

$0 \% \quad 20 \%$

$0 \%$

$++$

$+$

$+$

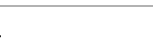

$+$

$+$

$+$

NH3-reductie afhankelijk van opp.

roostervloer)

Mestopvang in en spoelen met aangezuurde vloeistof

$0 \%$

$+$

(gedeeltelijk roostervloer)

Gescheiden afvoer van mest en urine door middel van

D 1.1.8

$67 \% \quad 70 \%{ }^{4} \quad 90 \%$

$0 \%$

$+$

$+$

$+5$

hellende mestband

\section{Kraamzeugen}

Spoelgotensysteem, spoelen met dunne mest

\begin{tabular}{|c|c|c|c|c|c|c|c|c|c|c|}
\hline Spoelgotensysteem, spoelen met dunne mest & D 1.2 .1 & $60 \%$ & $0 \%$ & $80 \%$ & $0 \%$ & + & + & - & 4 & \\
\hline Schuif onder rooster & $\begin{array}{c}\mathrm{D} 1.2 .2, \mathrm{D} \\
1.2 .3, \mathrm{D} 1.2 .4\end{array}$ & $\begin{array}{l}52- \\
63 \%\end{array}$ & $30 \%^{4}$ & $80 \%$ & $0 \%$ & + & ++ & + & 3 & $\begin{array}{l}\text { Ammoniakreductie afhankelijk van } \\
\text { precieze uitvoering }\end{array}$ \\
\hline
\end{tabular}

$60 \%-0 \%$

$80 \%$




\begin{tabular}{|c|c|c|c|c|c|c|c|c|c|c|}
\hline \multirow[t]{2}{*}{ Systeem } & \multirow[t]{2}{*}{ Rav code } & \multirow{2}{*}{$\begin{array}{l}\mathrm{NH3} \\
(\%)\end{array}$} & \multirow{2}{*}{$\begin{array}{l}\text { Geur } \\
(\%)\end{array}$} & \multirow{2}{*}{$\begin{array}{l}\text { Methaan } \\
(\%)\end{array}$} & \multirow{2}{*}{$\begin{array}{l}\text { Fijnstof } \\
(\%)\end{array}$} & \multirow{2}{*}{$\begin{array}{l}\text { Lucht } \\
\text { kwaliteit }^{\text {stal }^{1}}\end{array}$} & \multicolumn{2}{|c|}{ Kosten } & \multirow{2}{*}{$\begin{array}{l}\text { Betrouwbaarheid } \\
\text { / robuustheid } \\
\text { Systeem }^{3}\end{array}$} & \multirow[t]{2}{*}{ Opmerkingen } \\
\hline & & & & & & & Investering & Jaarlijks & & \\
\hline Ondiepe mestkelders met mest- en waterkanaal & D 1.2 .6 & $52 \%$ & $0 \%$ & $70 \%$ & $0 \%$ & + & 0 & - & 5 & \\
\hline Kraamopfokhok met hellende plaat & D 1.2 .7 & $40 \%$ & $0 \%$ & $70 \%$ & $0 \%$ & + & + & 0 & 5 & \\
\hline Mestopvang in en spoelen met aangezuurde vloeistof & D 1.2 .8 & $63 \%$ & $0 \%$ & $70 \%$ & $0 \%$ & + & + & 0 & 3 & $\begin{array}{l}\text { Spoelen/zuur toevoegen en } \\
\text { spoelvloeistof maken }\end{array}$ \\
\hline Mestpan / mestbak & $\begin{array}{c}\mathrm{D} 1.2 .13, \mathrm{D} \\
1.2 .14, \mathrm{D} \\
1.2 .16\end{array}$ & $65 \%$ & $0 \%$ & $70 \%$ & $0 \%$ & + & + & - & 5 & \\
\hline \multicolumn{11}{|l|}{ Dragende zeugen } \\
\hline $\begin{array}{l}\text { Mestopvang in en spoelen met aangezuurde vloeistof bij } \\
\text { groepshuisvesting }\end{array}$ & D 1.3 .4 & $57 \%$ & $0 \%$ & $80 \%$ & $0 \%$ & + & + & 0 & 3 & $\begin{array}{l}\text { Spoelen/zuur toevoegen en } \\
\text { spoelvloeistof maken }\end{array}$ \\
\hline Koeldeksysteem & D 1.3 .8 & $48 \%$ & $0 \%$ & $40 \%$ & $0 \%$ & + & 0 & - & 2 & $\begin{array}{l}\text { In kader van dikke mest minder } \\
\text { robuust }\end{array}$ \\
\hline $\begin{array}{l}\text { Groepshuisvestingssysteem met voerligboxen of } \\
\text { zeugenvoerstations, zonder strobed, met schuine } \\
\text { putwanden }\end{array}$ & D 1.3 .9 & $\begin{array}{l}40- \\
45 \%\end{array}$ & $0 \%$ & $30 \%$ & $0 \%$ & + & + & - & 5 & $\begin{array}{l}\text { NH3 reductie afhankelijk type } \\
\text { rooster }\end{array}$ \\
\hline Rondloopstal met zeugenvoerstation en strobed & D 1.3 .10 & $38 \%$ & $20 \%{ }^{4}$ & $30 \%$ & $0 \%$ & + & 0 & - & 5 & \\
\hline $\begin{array}{l}\text { Gescheiden afvoer van mest en urine door middel van een } \\
\text { V-vormige mestband }\end{array}$ & D 1.3 .15 & $48 \%$ & $50 \%{ }^{4}$ & $80 \%$ & $20 \%{ }^{4}$ & + & ++ & + & 3 & $\begin{array}{l}\text { Draaiende delen in } \\
\text { mestput/driekant rooster }\end{array}$ \\
\hline Mestopvang in en spoelen met NH3 arme vloeistof (incl. & D 3.2 .2 & $47 \%$ & $22 \%$ & $80 \%$ & $0 \%$ & ++ & 0 & - & 3 & Spoelen en zuur \\
\hline
\end{tabular}




\begin{tabular}{|c|c|c|c|c|c|c|c|c|c|c|}
\hline \multirow[t]{2}{*}{ Systeem } & \multirow[t]{2}{*}{ Rav code } & \multirow{2}{*}{$\begin{array}{l}\mathrm{NH3} \\
(\%)\end{array}$} & \multirow{2}{*}{$\begin{array}{l}\text { Geur } \\
(\%)\end{array}$} & \multirow{2}{*}{$\begin{array}{l}\text { Methaan } \\
\qquad(\%)\end{array}$} & \multirow{2}{*}{$\begin{array}{l}\text { Fijnstof } \\
(\%)\end{array}$} & \multirow{2}{*}{$\begin{array}{l}\text { Lucht } \\
\text { kwaliteit } \\
\text { stal }^{1}\end{array}$} & \multicolumn{2}{|c|}{ Kosten } & \multirow{2}{*}{$\begin{array}{l}\text { Betrouwbaarheid } \\
\text { / robuustheid } \\
\text { Systeem }^{3}\end{array}$} & \multirow[t]{2}{*}{ Opmerkingen } \\
\hline & & & & & & & Investering & Jaarlijks & & \\
\hline Koeldeksysteem & $\begin{array}{l}\text { D 3.2.3, D } \\
3.2 .6\end{array}$ & $\begin{array}{l}20- \\
60 \%\end{array}$ & $22 \%$ & $40 \%$ & $0-20 \%^{4}$ & $+/++$ & - & - & 2 & $\begin{array}{l}\text { NH3-reductie afhankelijk van } \\
\text { koelopp., emitterend opp. en type } \\
\text { rooster. } \\
\text { Fijnstofreductie afhankelijk van } \\
\text { type rooster. } \\
\text { Door dikke mest minder robuust. }\end{array}$ \\
\hline $\begin{array}{l}\text { Mestopvang in water in combinatie met metalen driekant- } \\
\text { roostervloer }\end{array}$ & D 3.2 .5 & $57 \%$ & $22 \%$ & $60 \%$ & $20 \%{ }^{4}$ & ++ & 0 & - & 5 & Wel veel water \\
\hline Mestkelders met water- en mestkanaal & D 3.2 .7 & $\begin{array}{l}37- \\
67 \%\end{array}$ & $22 \%$ & $70 \%$ & $0-20 \% 4$ & ++ & -- & -- & 5 & $\begin{array}{l}\text { NH3-reductie afhankelijk van } \\
\text { emitterend opp. en type rooster. } \\
\text { Fijnstofreductie afhankelijk van } \\
\text { type rooster. } \\
\text { Verstopping overloop voorkomen. }\end{array}$ \\
\hline $\begin{array}{l}\text { Bollevloerhok met betonnen morsrooster en metalen } \\
\text { driekantrooster }\end{array}$ & D 3.2 .10 & $\begin{array}{l}33- \\
53 \%\end{array}$ & $22 \%$ & $30 \%$ & $20 \%{ }^{4}$ & ++ & -- & -- & 5 & \\
\hline Hok met gescheiden mestkanalen en driekant roosters & D 3.2 .11 & $43 \%$ & $22 \%$ & $20 \%$ & $20 \%{ }^{4}$ & ++ & -- & -- & 5 & \\
\hline Spoelgotensysteem & $\begin{array}{l}\text { D } 3.2 .12, \mathrm{D} \\
\quad 3.2 .13\end{array}$ & $\begin{array}{l}43- \\
60 \%\end{array}$ & $0 \%$ & $80 \%$ & $0-20 \%{ }^{4}$ & ++ & + & + & 3 & $\begin{array}{l}\mathrm{NH} 3 \text { en fijnstof reductie afhankelijk } \\
\text { type rooster. } \\
\text { Spoelen en dunne fractie. }\end{array}$ \\
\hline $\begin{array}{l}\text { Gescheiden afvoer van mest en urine door middel van een } \\
\text { V-vormige mestband }\end{array}$ & D 3.2 .16 & $63 \%$ & $70 \%$ & $90 \%$ & $20 \%{ }^{4}$ & ++ & ++ & + & 3 & Draaiende delen in mestput \\
\hline
\end{tabular}

1) 0 = geen effect; +/- = effect onbekend; + = gematigd positief; ++ = positief; +++ = zeer positief

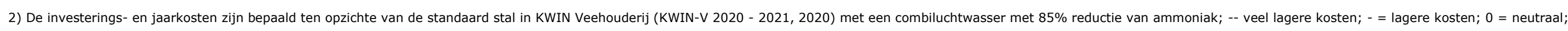
$+=$ hogere kosten; $++=$ veel hogere kosten

3) Schaal van $1 \mathrm{t} / \mathrm{m} 5$, waarin $1=$ systeem is onbetrouwbaar/ niet robuust en $5=$ systeem is betrouwbaar/ robuust

4) Afgeweken van de Rav-lijst 


\subsection{Kansrijke nieuwe brongerichte maatregelen}

In dit hoofdstuk wordt antwoord gegeven op vraag $3 \mathrm{t} / \mathrm{m} 6$ :

- Welke nieuwe brongerichte maatregelen zijn in ontwikkeling en welke bedrijven bieden dit systeem aan?

- In welke fase van de innovatiecyclus bevindt dit systeem zich en wanneer is het klaar voor implementatie?

- Wat zijn de potentiële emissiereducties die behaald kunnen worden en welk effect heeft het op de kwaliteit van de stallucht?

- Wat zijn de investerings- en jaarkosten voor deze systemen?

Het antwoord op deze vragen wordt gegeven in Tabel 3. Deze tabel bevat emissie reducerende maatregelen welke in ontwikkeling zijn bij verscheidene partijen. De tabel geeft de bijbehorende verwachte reductiepercentages voor ammoniak, methaan, geur en fijnstof. Daarnaast zijn de verbetering van de luchtkwaliteit in de stal, investerings- en jaarkosten, en de fase van de innovatiecyclus (TRL, Technology Readiness Level) weergegeven. Uitleg over de TRL fases is terug te vinden in Bijlage 2.

Uit Tabel 3 kan het volgende worden geconcludeerd:

- De kansrijke initiatieven met brongerichte maatregelen voor emissiereductie worden gekenmerkt door één of een combinatie van onderstaande kenmerken:

Korte opslagduur van de mest in de stal (dagontmesting)

Mestverwijdering via schuiven, spoelen of met een mestband

Klein emitterend oppervlak

Goed doorlatende roostervloeren (vooral vleesvarkens)

Koelen van de mest

Verdunnen van de mest (waterkanaal, ammoniak- en geurvrije vloeistof)

Mestscheiding (schuifsystemen, mestbanden)

- De brongerichte maatregelen in Tabel 3 reduceren naar verwachting de ammoniak- en methaanemissies met tenminste $70 \%$. De geuremissie wordt naar verwachting met $50 \%$ of meer gereduceerd. Fijnstof wordt in het algemeen maar zeer beperkt gereduceerd.

- De investeringskosten zijn in het algemeen hoger dan voor de standaard stal met luchtwasser. De jaarkosten zijn naar verwachting vergelijkbaar met de referentiestal.

- De verwachting is dat de meeste systemen voor of rond 2025 in de markt kunnen worden gezet.

In Tabel 4 zijn systemen opgenomen die nog in de beginfase zitten van de ontwikkeling en/of waar zich in Nederland nog geen marktpartij mee bezighoudt.

Uit Tabel 4 kan het volgende worden geconcludeerd:

- De brongerichte maatregelen in Tabel 4 geven naar verwachting een integrale reductie van de verschillende emissies. Alleen wordt met het systeem van luchtrecirculatie geen methaanreductie bereikt. Dit kan alleen bereikt worden in combinatie met een andere maatregel, b.v. het dagelijks verwijderen van de mest uit de stal. Fijnstof lijkt bij alle vermelde systemen ook gereduceerd te worden.

- De kosten zijn voor een paar systemen nog niet goed aan te geven en voor de andere systemen hoger dan voor de standaard stal met luchtwasser.

- De verwachting is dat deze systemen pas op de markt komen in 2025 of later.

In Tabel 5 zijn specifieke brongerichte en nageschakelde technieken voor fijnstofreductie opgenomen. De meeste systemen, behalve de olienippel, komen uit de pluimveehouderij en zijn in de varkenshouderij nog niet of beperkt onderzocht. In varkenstallen worden echter vergelijkbare effecten verwacht als in de pluimveehouderij. 
Het effect van de olienippel is onderzocht bij vleesvarkens, maar zou ook bij gespeende biggen en dragende zeugen toegepast kunnen worden. Bij biggen op een volledige roostervloer lijkt dit systeem echter minder effectief. 
Tabel 3 Kansrijke brongerichte initiatieven voor integrale emissiereductie uit bestaande en nieuw te bouwen stallen, met een inschatting van de te verwachten emissiereducties en effect op de luchtkwaliteit. Tevens is aangegeven voor welke categorieën varkens deze initiatieven geschikt zijn, wat de investerings- en jaarkosten zijn, in welke fase van innovatie deze initiatieven zich bevinden en in welk jaar deze innovatie naar verwachting uitgerold kan worden in de praktijk (TRL = 9). Opmerking: de aangegeven emissiereducties zijn indicatief, afgerond op 5\%, in het algemeen nog niet gemeten en gebaseerd op een goede werking van het systeem. Voor ammoniak zijn de schattingen vooral gebaseerd op modelberekeningen en voor geur, methaan en fijnstof vooral op expertkennis.

\begin{tabular}{|c|c|c|c|c|c|c|c|c|c|c|c|}
\hline Initiatief + bedrijven & Belangrijkste principes & $\begin{array}{l}\text { NH3 } \\
(\%)\end{array}$ & $\begin{array}{l}\text { Geur } \\
(\%)\end{array}$ & $\begin{array}{l}\text { Methaan } \\
(\%)\end{array}$ & $\begin{array}{l}\text { Fijnstof } \\
(\%)\end{array}$ & $\begin{array}{l}\text { Lucht } \\
\text { kwaliteit stal }{ }^{1}\end{array}$ & $\begin{array}{l}\text { Catego- } \\
\text { rieën }{ }^{2}\end{array}$ & Kosten ${ }^{3}$ & $\begin{array}{l}\text { Betrouwbaarheid } \\
\text { / robuustheid } \\
\text { systeem }^{4}\end{array}$ & $\mathrm{TRL}^{5}$ & $\mathrm{TRL}^{5}=9$ \\
\hline
\end{tabular}

\begin{tabular}{|c|c|c|c|c|c|c|c|c|c|c|c|c|}
\hline $\begin{array}{l}\text { Dagontmesting } \\
\text { - De Hoeve Innovatie; } \\
\text { Stal vd Toekomst }\end{array}$ & $\begin{array}{l}\text { Verkleining emitterend oppervlak door } \\
\text { veel dichte vloer en schuine wanden; } \\
\text { water- en mestkanaal; koeling; } \\
\text { dagontmesting; driekantroosters }\end{array}$ & $75 \%$ & $50 \%$ & $80 \%$ & $0 \%$ & +++ & $\begin{array}{l}B, K, V^{7} \\
D^{7}\end{array}$ & $0 /+$ & $?$ & 4 & $\begin{array}{l}7 \\
5\end{array}$ & $\begin{array}{l}2022 \\
2023\end{array}$ \\
\hline $\begin{array}{l}\text { ZERO-STAL } \\
\text { - Agrifirm }\end{array}$ & $\begin{array}{l}\text { Mestscheiding, ammonia retention } \\
\text { technique (ART), ammoniakarme vloeistof } \\
\text { in mestkanaal, driekantroosters }\end{array}$ & $70 \%$ & $50 \%$ & $80 \%$ & $20 \%$ & +++ & Alle $^{8}$ & ++ & $?$ & 3 & 4 & 2025 \\
\hline $\begin{array}{l}\text { Ammoniak- en geurvrije } \\
\text { vloeistof } \\
\text { - Kamplan }\end{array}$ & $\begin{array}{l}\text { Mestscheiding, beluchten, ammoniakarme } \\
\text { vloeistof in mestkanaal, driekantroosters }\end{array}$ & $75 \%$ & $60 \%$ & $80 \%$ & $20 \%$ & +++ & Alle $^{8}$ & + & 0 & 3 & 6 & 2023 \\
\hline $\begin{array}{l}\text { Mestschuif } \\
\text { - Vd Sande e.a. } \\
\text { - TRAC, Cooperl } \\
\text { - JOZ } \\
\text { - IM-Aces } \\
\text { - Tribunestal }\end{array}$ & $\begin{array}{l}\text { Mestschuif over gecoate hellende of } \mathrm{V} \text { - } \\
\text { vormige vloer onder rooster i.c.m. coating } \\
\text { en sproeien met water en eventueel } \\
\text { ureaseremmer }\end{array}$ & $75 \%$ & $60 \%$ & $90 \%$ & $10 \%$ & +++ & alle & 0 & $-/ 0$ & 3 & 5 & 2025 \\
\hline $\begin{array}{l}\text { Varkenstoilet; } \\
\text { - Familievarken } \\
\text { - Pigster } \\
\text { - Zonvarken }\end{array}$ & $\begin{array}{l}\text { Varkenstoilet; klein emitterend } \\
\text { mestoppervlak }\end{array}$ & $70 \%$ & $60 \%$ & $80 \%$ & $30 \%^{9}$ & +++ & alle & ++ & ++ & 3 & 5 & $>2025$ \\
\hline
\end{tabular}




\begin{tabular}{|c|c|c|c|c|c|c|c|c|c|c|c|c|}
\hline Initiatief + bedrijven & Belangrijkste principes & $\begin{array}{l}\mathrm{NH} 3 \\
(\%)\end{array}$ & $\begin{array}{l}\text { Geur } \\
(\%)\end{array}$ & $\begin{array}{l}\text { Methaan } \\
(\%)\end{array}$ & $\begin{array}{l}\text { Fijnstof } \\
(\%)\end{array}$ & $\begin{array}{l}\text { Lucht } \\
\text { kwaliteit stal }^{1}\end{array}$ & $\begin{array}{l}\text { Catego- } \\
\text { rieën }{ }^{2}\end{array}$ & Kosten ${ }^{3}$ & & $\begin{array}{l}\text { Betrouwbaarheid } \\
\text { / robuustheid } \\
\text { systeem }{ }^{4}\end{array}$ & TRL $^{5}$ & $\mathrm{TRL}^{5}=9$ \\
\hline $\begin{array}{l}\text { Gekoelde mestpan } \\
\text { - IC \& R\&R }\end{array}$ & $\begin{array}{l}\text { Gekoelde mestpannen in combi met } \\
\text { driekant roosters }\end{array}$ & $70 \%$ & $50 \%$ & $70 \%$ & $20 \%$ & +++ & $\begin{array}{l}B, D^{8}, V \\
K\end{array}$ & $\begin{array}{l}+ \\
+\end{array}$ & $\begin{array}{l}0 \\
0\end{array}$ & $\begin{array}{l}5 \\
5\end{array}$ & $\begin{array}{l}5 \\
9\end{array}$ & $\begin{array}{l}2024 \\
2021\end{array}$ \\
\hline $\begin{array}{l}\text { Mestband; } \\
\text { • Nooyen }\end{array}$ & Bolle mestband / V-vormige mestband & $60 \%$ & $60 \%$ & $90 \%$ & $0 \%$ & ++ & D & + & 0 & 3 & 5 & 2025 \\
\hline $\begin{array}{c}\text { - Kempfarm / } \\
\text { Wopereis }\end{array}$ & & $70 \%$ & $60 \%$ & $90 \%$ & $0 \%$ & ++ & v & + & 0 & & 5 & 2025 \\
\hline $\begin{array}{l}\text { Wroetstal } \\
\text { - Mts. De Jong } \\
\text { - Bruns, Jansen, Tijink }\end{array}$ & $\begin{array}{l}\text { Sturing mestgedrag, mestverwijdering } \\
\text { met schuif, sproeien met water en EOW }\end{array}$ & $75 \%$ & $60 \%$ & $90 \%$ & $0 \%$ & ++ & $B, V$ & + & 0 & 3 & 5 & 2025 \\
\hline $\begin{array}{l}\text { Mestgoten met schuif } \\
\text { - Jovas, Duosep }\end{array}$ & $\begin{array}{l}\text { Mestgoten met schuine wanden i.c.m. } \\
\text { kleine mestschuif; scheiding urine en } \\
\text { feces }\end{array}$ & $70 \%$ & $50 \%$ & $80 \%$ & $0 \%$ & +++ & alle & + & 0 & 3 & 4 & 2025 \\
\hline $\begin{array}{l}\text { Geperforeerde } \\
\text { mestband } \\
\text { - Big Dutchman } \\
\text { (Havito) } \\
\text { - Filterfloor }\end{array}$ & $\begin{array}{l}\text { Een geperforeerde mestband waar urine } \\
\text { doorheen stroomt; feces worden } \\
\text { afgedraaid; om voldoende reductie te } \\
\text { behalen moet dit gecombineerd worden } \\
\text { met sproeien water en urease-remmer }\end{array}$ & $70 \%$ & $50 \%$ & $90 \%$ & $40 \%$ & +++ & $B, D, V$ & + & 0 & $2 / 3$ & 5 & 2025 \\
\hline
\end{tabular}

1) 0 = geen effect; $+/-=$ effect onbekend; + = gematigd positief; $++=$ positief; $+++=$ zeer positief

2) Bij welke categorieën varkens kan de maatregel worden toegepast; alle = bij alle categorieën; $B=$ bij biggen; $D=$ bij dragende zeugen; $K=$ bij kraamzeugen; $V=$ bij vleesvarkens

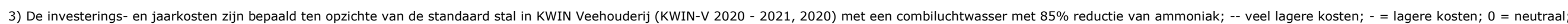
$+=$ hogere kosten; $++=$ veel hogere kosten

4) Schaal van $1 \mathrm{t} / \mathrm{m} 5$, waarin $1=$ systeem is onbetrouwbaar/ niet robuust en $5=$ systeem is betrouwbaar/ robuust

5) $\mathrm{TRL}=$ technology readiness level, zie bijlage 2

6) Schal van $1 \mathrm{t} / \mathrm{m} 5$, warin 1 = systeem is extreem gevoelig voor fouten en $5=$ systeem werkt geheel naar behoren zonder fouten

7) Voor biggen, dragende zeugen en vleesvarkens zijn voorlopige emissiefactoren vastgesteld. Voor dragende zeugen is het systeem nog in ontwikkeling.

8) Driekantroosters zijn minder geschikt voor dragende zeugen, eventueel zou een deel van de roostervloer, waar naar verwachting veel wordt gemest, als driekantrooster kunnen worden uitgevoerd.

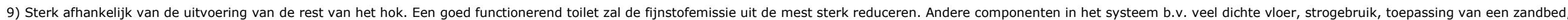
kunnen zorgen voor verhoogde fijnstofemissies. 


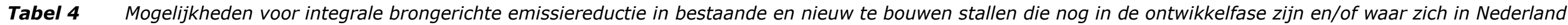
nog geen marktpartij mee bezighoudt. De tabel geeft een inschatting van de emissiereducties en het effect op de luchtkwaliteit. Tevens is aangegeven voor welke categorieën varkens deze initiatieven geschikt zijn, wat de investerings- en jaarkosten zijn, in welke fase van innovatie deze initiatieven zich bevinden en in welk jaar deze innovatie naar verwachting uitgerold kan worden in de praktijk (TRL =9). Opmerking: de aangegeven emissiereducties zijn indicatief, afgerond op 5\%, in het algemeen nog niet gemeten en gebaseerd op een optimale werking van het systeem. Voor ammoniak zijn de schattingen vooral gebaseerd op modelberekeningen en voor geur, methaan en fijnstof vooral op expertkennis.

\begin{tabular}{|c|c|c|c|c|c|c|c|c|c|c|c|c|}
\hline \multirow[t]{2}{*}{ Initiatief } & \multirow[t]{2}{*}{ Belangrijkste principes } & \multirow{2}{*}{$\begin{array}{l}\mathrm{NH3} \\
(\%)\end{array}$} & \multirow{2}{*}{$\begin{array}{l}\text { Geur } \\
(\%)\end{array}$} & \multirow{2}{*}{$\begin{array}{l}\text { Methaan } \\
(\%)\end{array}$} & \multirow{2}{*}{$\begin{array}{c}\text { Fijnstof } \\
(\%)\end{array}$} & \multirow{2}{*}{$\begin{array}{l}\text { Luchtkwaliteit } \\
\text { stal }^{1}\end{array}$} & \multirow{2}{*}{$\begin{array}{l}\text { Catego } \\
\text {-rieën }\end{array}$} & \multicolumn{2}{|c|}{ Kosten ${ }^{3}$} & \multirow{2}{*}{$\begin{array}{l}\text { Betrouwbaarheid } \\
\text { / robuustheid } \\
\text { systeem }{ }^{4}\end{array}$} & \multirow[t]{2}{*}{$\mathrm{TRL}^{5}$} & \multirow[t]{2}{*}{$\mathrm{TRL}^{5}=9$} \\
\hline & & & & & & & & Investering & Jaarlijks & & & \\
\hline $\begin{array}{l}\text { Deens systeem } \\
\text { aanzuren }\end{array}$ & $\begin{array}{l}\text { Scheiding mest; aanzuren dunne fractie en } \\
\text { terugzetten in mestput; driekantroosters }\end{array}$ & $80 \%$ & $20 \%$ & $90 \%$ & $20 \%$ & +++ & alle $^{5}$ & $?$ & $?$ & 3 & 5 & $>2025$ \\
\hline $\begin{array}{l}\text { Koude plasma- } \\
\text { technologie } \\
\text { Blue reactor, Blue } \\
\text { Plasma }\end{array}$ & $\begin{array}{l}\text { Koude plasmatechnologie met interne } \\
\text { circulatie }\end{array}$ & $70 \%$ & $70 \%$ & $70 \%$ & $70 \%$ & +++ & alle & $?$ & $?$ & 3 & 3 & $>2025$ \\
\hline $\begin{array}{l}\text { Pig on the moon } \\
\text { (Denemarken) }\end{array}$ & $\begin{array}{l}\text { Mestpan met (gedeeltelijke) onderafzuiging } \\
\text { lucht i.c.m. luchtwasser }\end{array}$ & $75 \%$ & $30 \%$ & $50 \%$ & $20 \%$ & +++ & alle & + & 0 & $3 / 4$ & 3 & 2025 \\
\hline Luchtrecirculatie & $\begin{array}{l}\text { Gedeeltelijke recirculatie van lucht in combi } \\
\text { met luchtzuivering en luchtconditionering }\end{array}$ & $90 \%$ & $50 \%$ & $0 \%$ & $85 \%$ & ++ & alle & + & + & $3 / 4$ & 4 & $>2025$ \\
\hline Strostal zeugen & $\begin{array}{l}\text { Strostal met gescheiden opvang mest en } \\
\text { urine bij dragende zeugen, schuiven en } \\
\text { sproeien }\end{array}$ & $70 \%$ & $40 \%$ & $70 \%$ & $50 \%$ & +++ & D & + & + & 3 & iv & \\
\hline
\end{tabular}

1) $0=$ geen effect; $+/-=$ effect onbekend; $+=$ gematigd positief; $++=$ positief; $+++=$ zeer positief

2) Bij welke categorieën varkens kan de maatregel worden toegepast; alle = bij alle categorieën; $\mathrm{B}=$ bij biggen; $\mathrm{D}=$ bij dragende zeugen; $\mathrm{K}=$ bij kraamzeugen; $\mathrm{V}=$ bij vleesvarken

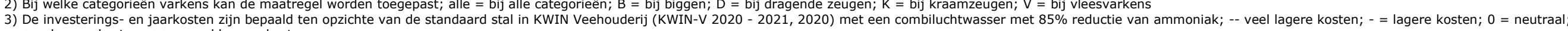
$+=$ hogere kosten; $++=$ veel hogere kosten
4) Schaal van 1 t/m 5 , waarin $1=$ systeem is onbetro

5) $T R L=$ technology readiness level, zie bijlage 2 


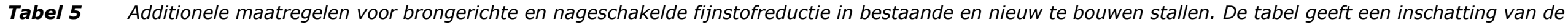
emissiereducties en het effect op de luchtkwaliteit. Tevens is aangegeven voor welke categorieën varkens deze initiatieven geschikt zijn, wat de investerings- en jaarkosten zijn, in welke fase van innovatie deze initiatieven zich bevinden en in welk jaar deze innovatie naar verwachting uitgerold kan worden in de praktijk (TRL = 9). Opmerking: de aangegeven emissiereducties zijn indicatief, afgerond op 5\% en gebaseerd op een goede werking van het systeem.

\begin{tabular}{|c|c|c|c|c|c|c|c|c|c|c|c|c|}
\hline \multirow[t]{2}{*}{ Initiatief + bedrijven } & \multirow[t]{2}{*}{ Belangrijkste principes } & \multirow{2}{*}{$\begin{array}{l}\text { NH3 } \\
(\%)\end{array}$} & \multirow{2}{*}{$\begin{array}{l}\text { Geur } \\
(\%)\end{array}$} & \multirow{2}{*}{$\begin{array}{c}\text { Methaan } \\
(\%)\end{array}$} & \multirow{2}{*}{$\begin{array}{l}\text { Fijnstof } \\
(\%)\end{array}$} & \multirow{2}{*}{$\begin{array}{l}\text { Luchtkwaliteit } \\
\text { stal }^{1}\end{array}$} & \multirow{2}{*}{$\begin{array}{l}\text { Catego- } \\
\text { rieën }{ }^{2}\end{array}$} & \multicolumn{2}{|c|}{ Kosten ${ }^{3}$} & \multirow{2}{*}{$\begin{array}{l}\text { Betrouwbaarheid/ } \\
\text { robuustheid } \\
\text { systeem }^{4}\end{array}$} & \multirow[t]{2}{*}{$\mathrm{TRL}^{5}$} & \multirow[t]{2}{*}{$T R L^{5}=9$} \\
\hline & & & & & & & & $\begin{array}{l}\text { Investe- } \\
\text { ring }\end{array}$ & Jaarlijks & & & \\
\hline $\begin{array}{l}\text { Ionisatie van de lucht } \\
\text { (Gastrion, Freshlight Agri ,IC } \\
\text { ionic, ENS) }\end{array}$ & Ionisatie van lucht & $0 \%$ & $0 \%$ & $0 \%$ & $\begin{array}{l}30- \\
50 \%\end{array}$ & + & alle & + & + & 3 & 9 & 2021 \\
\hline $\begin{array}{l}\text { Olienippel } \\
\text { (Schippers Bladel) }\end{array}$ & $\begin{array}{l}\text { Oliedruppels op huid dier zodat stof gaat } \\
\text { plakken }\end{array}$ & $0 \%$ & $0 \%$ & $0 \%$ & $60 \%$ & + & $B, D, V$ & + & + & 3 & 9 & 2021 \\
\hline Warmtewisselaar ${ }^{6}$ & & $0 \%$ & $0 \%$ & $0 \%$ & $31 \%$ & 0 & alle & + & + & 3 & 9 & 2021 \\
\hline Luchtconditioneringsunit ${ }^{6}$ & & $0 \%$ & $0 \%$ & $0 \%$ & $80 \%$ & 0 & alle & ++ & ++ & 3 & 9 & 2021 \\
\hline Stoffilters ${ }^{6}$ & & $0 \%$ & $0 \%$ & $0 \%$ & $1-95 \%^{7}$ & 0 & alle & ++ & ++ & 3 & 9 & 2021 \\
\hline
\end{tabular}

1) $0=$ geen effect; $+/-=$ effect onbekend; $+=$ gematigd positief; $++=$ positief; $+++=$ zeer positief

2) Bij welke categorieën varkens kan de maatregel worden toegepast; alle = bij alle categorieën; $B=$ bij biggen; $D=$ bij dragende zeugen; $K=$ bij kraamzeugen; $V=$ bij vleesvarkens

$+=$ hogere kosten; $++=$ veel hogere kosten
4) Schaal van $1 \mathrm{t} / \mathrm{m} 5$, waarin $1=$ systeem is onbetrouwbaar/ niet robuust en $5=$ systeem is betrouwbaar/ robuust

5) $\mathrm{TRL}=$ technology readiness level, zie bijlage 2

6) Nageschakelde technieken voor fijnstof welke goedgekeurd zijn voor pluimvee, maar nog bij varkens getest moeten worden
7) Dit percentage verschilt aan de hand van de hoeveelheid ventilatie door het filter. Bij een minimale ventilatie is de reductie $1 \%$ en bij een maximale ventilatie $95 \%$ 


\section{Discussie}

Kenmerken systemen met brongerichte emissiereductie

De verschillende tabellen in hoofdstuk 3 laten zien dat er veel systemen beschikbaar zijn of beschikbaar komen die een sterke brongerichte reductie geven van ammoniak en methaan uit de stal. Deze systemen hebben één of meerdere van de volgende kenmerken:

- Korte opslagduur van de mest in de stal (dagelijks of (twee)wekelijks afvoeren van de mest uit de stal)

- Mestverwijdering via schuiven, spoelen of met een mestband

- Klein emitterend oppervlak (geringe vloerbevuiling en klein emitterend mestoppervlak in kelder)

- Goed doorlatende roostervloeren (vooral vleesvarkens)

- Koelen van de mest

- Verdunnen van de mest (waterkanaal, ammoniak- en geurvrije vloeistof)

- Mestscheiding (schuifsystemen, mestbanden)

Om te voorkomen dat ammoniak verderop in de keten alsnog emitteert uit de mest is het belangrijk dat deze mest vrijwel luchtdicht wordt opgeslagen en emissiearm wordt aangewend of wordt verwerkt tot mestproducten. Voorgaande wordt op dit moment al min of meer standaard gedaan. Voor methaan is vrijwel luchtdicht afsluiten van de mestopslag niet voldoende. In tegenstelling tot ammoniak is methaan vrijwel niet oplosbaar in mest. Dit betekent dat wanneer het gevormd wordt dit ook gaat emitteren, tenzij de mestopslag echt luchtdicht wordt afgesloten, b.v. in een biogasinstallatie waarbij het geproduceerde biogas wordt benut als energiebron. Om methaanproductie in de mest buiten de stal te voorkomen is het daarom belangrijk om de mest zo kort mogelijk op te slaan en direct te gebruiken op het land of te verwerken tot producten waarin geen methaan meer kan worden gevormd.

De huidige systemen die geur reduceren hebben één of meerdere van de volgende kenmerken:

- Schuiven of mestbanden onder de roostervloer met dagelijkse mestverwijdering

- Regelmatige mestverwijdering (dagelijks/wekelijks) in hokken met water- en mestkanaal (gespeende biggen en vleesvarkens)

- Rondloopstal met strobed voor dragende zeugen

Vooral bij kraamzeugen zijn er op dit moment weinig systemen beschikbaar die geur reduceren. Opgemerkt moet worden dat de geuremissies van brongerichte emissiereductie-maatregelen nog maar beperkt bemeten zijn. Dit is, naast de grote variatie in de metingen, ook de reden dat er in de Ravlijst weinig onderscheid wordt gemaakt tussen de verschillende systemen in geuremissiefactoren.

De kansrijke nieuwe initiatieven (tabel 3) kenmerken zich als volgt t.a.v. de te verwachten geurreductie van $50-60 \%$ ten opzichte van de categorie 'Overige huisvestingssystemen' in de Ravlijst:

- Snelle en volledige verwijdering van de mest, al dan niet na directe scheiding in de stal

- Opvang van de mest in ammoniak- en geurarme vloeistof

- Sturen mestgedrag naar een 'toilet' waardoor de feces en urine snel en volledig kunnen worden afgevoerd

- Mestkoeling van onderaf (gekoelde mestpan)

Net als voor ammoniak geldt ook voor geur dat het belangrijk dat de mest buiten de stal vrijwel luchtdicht wordt opgeslagen en emissiearm wordt aangewend of wordt verwerkt tot mestproducten.

Aangezien de meeste brongerichte systemen die de emissies reduceren zijn gericht op de mest in de mestkelders, hebben deze maatregelen weinig of geen effect op de emissie van fijnstof. Fijnstof ontstaat immers vooral uit opgedroogde mest op de vloer en van bevuilde dieren en van huidschilfers van de dieren (Cambra-López et al., 2011). De volgende brongerichte maatregelen geven naar verwachting wel een reductie van de fijnstofemissie:

- Goed doorlatende roostervloeren (vooral bij vleesvarkens)

- Systemen die de mest vanaf de vloer verwijderen, zoals de geperforeerde mestband 
- Systemen die de mest op een kleine plek verzamelen en verder behandelen (varkenstoilet) Voorkomen van bevuiling van de vloer en van de dieren is daarom belangrijk om fijnstofemissie te reduceren. De hierboven genoemde maatregelen om fijnstof te reduceren zijn onderdeel van het gehele brongerichte emissiearme systeem. In tabel 5 zijn twee aanvullende maatregelen opgenomen die specifiek zijn gericht op fijnstofreductie, namelijk ionisatiesystemen en olienippels.

Ionisatiesystemen zijn vooral getest en bemeten in pluimveestallen. In één onderzoek bij vleesvarkens werd met een ionisatiesysteem een fijnstofreductie gevonden van gemiddeld $36 \%$ (Winkel et al., 2012). Dit valt binnen de range die gevonden is bij pluimvee (30 - 50\% reductie). De olienippel is bij varkens onderzocht en blijkt, bij een juiste afstelling van de oliedosering, goed te werken (Winkel et al., 2012).

\section{Nauwkeurigheid emissiereducties en robuustheid systemen}

De ingeschatte emissiereducties zoals aangegeven in de verschillende tabellen in hoofdstuk 3 zijn slechts indicaties van de te verwachten emissies. De inschattingen van deze emissiereducties zijn gebaseerd op een goede werking van het systeem. Hoe dit uiteindelijk uitwerkt in de praktijk is sterk afhankelijk van de precieze uitvoering, van het precieze management van het complete systeem en van het noodzakelijke onderhoud van de technische onderdelen van het systeem. De precieze uitvoering kan gecheckt worden door een goede en gedetailleerde beschrijving te maken van het systeem in een leaflet en deze beschrijving te gebruiken bij het ontwerp van de stal. Via een goede en regelmatige controle op de bedrijven zal gecheckt moeten worden of het management en het onderhoud van het systeem ook adequaat zijn. Omdat vooral de ammoniakreductie sterk afhankelijk is van de uitvoering en het management van het systeem, verdient het aanbeveling om de ammoniakemissie continu te monitoren m.b.v. ammoniak- en $\mathrm{CO}_{2}$-sensoren in enkele afdelingen die uitgerust zijn met het emissiearme systeem. De varkenshouder heeft daarmee continu inzicht in de ammoniakemissie en de luchtkwaliteit in zijn stal. De luchtkwaliteit in de stal is van direct belang voor de gezondheid en de productie van de varkens. Op basis van de continue metingen zijn ook verwachtingscurves te maken voor de ammoniakemissie in de volgende productieperioden. Deze verwachtingscurves kunnen rekening houden met eventuele verschillen tussen seizoenen. Als de ammoniakemissie afwijkt van deze verwachtingscurve kan dat reden zijn om het emissiearme systeem te controleren en waar nodig te verbeteren c.q. te onderhouden.

Het continu monitoren van de ammoniakemissie kan fraudegevoelig zijn. Echter, hiervoor zijn verschillende maatregelen te bedenken om dit te reduceren, b.v. het verzegelen van een meetsysteem om te voorkomen dat deze wordt verhangen en de mogelijkheid om continu de gemeten waarden met de verwachtingswaarden te vergelijken. Bij abrupte veranderingen kan een extra controle uitgevoerd worden.

Uit het CBS-rapport (van Bruggen \& Geertjes, 2019) blijkt dat emissiearme systemen minder efficiënt lijken te zijn voor ammoniak dan zou moeten op basis van de afgegeven emissiefactoren. In het CDMadvies (CDM, 2020) zijn hiervoor enkele mogelijke oorzaken aangegeven:

1. De systeembeschrijvingen zijn niet gedetailleerd genoeg waardoor sommige kritische aspecten van emissiereductie niet zijn opgenomen.

2. Het ontbreken van een 'managementprotocol', d.w.z. een overzicht van aanwijzingen en voorschriften om emissiearme stallen effectief te maken.

3. Er ontbreekt een (jaarlijkse) controle zoals bij een APK.

Noot: ten aanzien van bovenstaande moet worden vermeld dat in het CBS-onderzoek geen uitspraak kon worden gedaan over de effectiviteit van luchtwassers.

Ad 1.

Een zeer kritisch aspect van emissiereductie in varkenstallen is hokbevuiling. Hokbevuiling (bevuiling van dichte vloeren) heeft vooral een negatief effect op de emissie van ammoniak. Voorkomen van hokbevuiling moet daarom een uitgangspunt zijn bij elk hokontwerp. Hokbevuiling treedt op als het hok, voor het varken, niet logisch is ingedeeld in functiegebieden. Dit kan zowel met de hokvorm als met de hokinrichting te maken hebben. Daarnaast is een goed stalklimaat van essentieel belang om hokbevuiling tegen te gaan. Vooral in de zomerperiode liggen varkens vaak liever op een nietgeïsoleerde roostervloer dan op een geïsoleerde dichte vloer. Dit verkeerde liggedrag veroorzaakt dat de varkens ook verkeerd mestgedrag gaan vertonen, met hokbevuiling als gevolg. Koelsystemen, zoals vloerkoeling of koeling van de inkomende lucht, kunnen dit verkeerde liggedrag in de zomer voorkomen. 
Daarnaast ontbreekt in systeembeschrijvingen vaak een gedetailleerde beschrijving van hoe het emissiearme systeem moet worden gemanaged, zie ook het volgende punt.

Ad 2.

Voor een effectieve werking van het emissiearme systeem is een goed management van het systeem vaak essentieel. De gevoeligheid van het systeem voor invloeden van management is overigens sterk afhankelijk van het systeem. In de tabellen in hoofdstuk 3 hebben we hiervoor een score gegeven.

Een systeem dat niet betrouwbaar en niet robuust is, is voor de effectiviteit vaak sterk afhankelijk van een goed management. Het tegengestelde is het geval bij een betrouwbaar en robuust systeem. In alle gevallen geldt dat de invloed van management afneemt wanneer zaken meer en beter zijn geautomatiseerd. Voor geautomatiseerde systemen geldt dat er signaleringssystemen ingebouwd moeten worden als zich afwijkingen van de gewenste situatie voordoen. De data die verzameld wordt bij de monitoring van de verschillende onderdelen van het systeem kan tevens gebruikt worden voor (online) controle door externen. Voor alle systemen geldt dat regelmatige controle en onderhoud essentieel zijn om een juiste werking te garanderen. Een voldoende gedetailleerd managementprotocol kan hier belangrijk in ondersteunen.

Ad 3.

Het is ook belangrijk dat het systeem regelmatig, bijvoorbeeld jaarlijks, door externen wordt gecontroleerd op het goed functioneren.

Ook luchtwassers blijken niet altijd zodanig te functioneren dat ze de te verwachten emissiereducties behalen. Uit onderzoek van Melse et al. (2018) blijkt dat vooral combi-wassers een lagere ammoniaken geurreductie realiseerden dan opgenomen in respectievelijk de Rav- en Rgv-lijst. Het gemiddelde geurverwijderingspercentage van de combi-wassers bedroeg met $40 \%$ slechts de helft van het verwachte gemiddelde Rgv-reductieniveau (81\%). Voor ammoniakverwijdering was het verschil, met een gemiddeld gemeten percentage van $59 \%$, wat minder groot t.o.v. het verwachte Rav-percentage (85\%). Op basis van deze bevindingen zijn de geurreducties voor combi-wassers in de Rav-lijst aangepast. Sinds 1 januari 2016 is het verplicht dat alle luchtwassers zijn voorzien van een elektronisch monitoringssysteem. Hierbij worden meetwaarden ieder uur geregistreerd en gedurende vijf jaar bewaard (Stouthart et al., 2013). Naast dit monitoringssysteem is het noodzakelijk dat luchtwassers regelmatig worden onderhouden en gecontroleerd op effectiviteit. Door beter onderhoud en controle is de verwachting dat combi-wassers uiteindelijk wel het verwachte Rav-percentage van $85 \%$ reductie kunnen behalen. Ook de geurreducties kunnen verbeterd worden door goed onderhoud en controle. Echter voor het behalen van de verwachte geurreducties in de Rgv-lijst (gemiddeld $81 \%$ ) is waarschijnlijk meer nodig (N.W.M. Ogink, mondelinge mededeling, 2021).

\section{Brongerichte en/of nageschakelde technieken}

Het grote voordeel van brongerichte maatregelen om emissies te beperken is dat het stalklimaat hiermee duidelijk wordt verbeterd. In stallen zonder emissiearme maatregelen worden in de winter vaak hoge concentraties ammoniak gemeten. In het fijnstofonderzoek van ca. 10 jaar geleden werden daggemiddelde concentraties gemeten in vleesvarkensstallen die op konden lopen tot max. 60 ppm ammoniak. Ook bij gespeende biggen en dragende zeugen werden maximale daggemiddelde concentraties boven de 20 ppm gemeten. Door effectieve brongerichte maatregelen kunnen deze concentraties sterk worden verlaagd tot onder de 10 of zelfs onder de $5 \mathrm{ppm}$ (lopend onderzoek). Aangezien veel brongerichte maatregelen zijn gericht op een snelle verwijdering van de mest uit de stal, wordt de methaanemissie hiermee ook sterk gereduceerd. Naast vermindering van stikstofemissies is de vermindering van emissies van broeikasgassen één van de belangrijke opgaven voor de komende jaren. In varkensstallen emitteert methaan vooral uit de mest die langdurig wordt opgeslagen in de mestkelders. Door de relatief (ten opzichte van buitenopslag) hoge temperaturen van de mest in de stal wordt er relatief veel organische stof omgezet in methaan. Echter, zoals hiervoor aangegeven, is het belangrijk om te voorkomen dat methaan in het vervolg van de mestketen alsnog wordt gevormd en emitteert.

Het voordeel van luchtwassers als nageschakelde techniek is dat deze de emissies van vooral ammoniak sterk kunnen reduceren, variërend van 70 tot $95 \%$. Biologische en gecombineerde luchtwassers geven daarnaast ook een redelijke geurreductie (30 - 45\%) en een hoge fijnstofreductie $(60-80 \%)$. De verwachting is dat door gericht onderzoek de geurreductie van luchtwassers nog verbeterd kan worden de komende jaren. Voor de huidige luchtwassers geldt dat ze methaan niet uit de lucht kunnen halen. Een ander belangrijk nadeel van luchtwassers is dat compartimentering van stallen in verband met brandveiligheid moeilijk is te realiseren. Dit zal ook de nodige aandacht vergen in de komende jaren. 
Uit de voorbeelden in paragraaf 3.1 blijkt dat door de combinatie van brongerichte en nageschakelde technieken er een sterke integrale reductie kan worden bereikt van alle vervuilende componenten (ammoniak, geur, methaan en fijnstof). Een belangrijk nadeel hiervan is echter dat de kosten hiermee sterk worden verhoogd. Veel varkenshouders zijn vaak om de volgende twee redenen gemotiveerd om brongerichte maatregelen toe te passen: 1) verbetering van het stalklimaat; 2) besparing op kosten nageschakelde techniek. Voor sommige varkenshouders is 3) brandveiligheid ook een belangrijke reden. Er is een groter risico op het afbranden van een stal doordat deze is aangesloten op het centrale afzuigkanaal op de kopgevel. Wanneer er brand ontstaat, verspreidt deze zich snel doordat dit één groot compartiment is en hier een verzameling van stof ontstaat door het ventilatiesysteem uit de verschillende varkensafdelingen (Bokma-Bakker et al., 2012). Door een combinatie van brongerichte en nageschakelde technieken verdwijnen de voordelen van punt 2 en 3.

Visie t.a.v. implementatie brongerichte emissiearme systemen

Nationaal en provinciaal emissiebeleid verschillen momenteel van elkaar. Noord Brabant, Limburg en Utrecht hanteren een minimale emissiereductie van $85 \%$ voor nieuwe en te verbouwen stallen voor alle varkenscategorieën. Dit verschilt van de andere provincies waar ca. 50-60\% aangehouden wordt afhankelijk van de diercategorie. Uit de verschillende tabellen in hoofdstuk 3 blijkt dat met brongerichte maatregelen heel moeilijk hogere ammoniakreducties zijn te behalen dan ca. $75 \%$. Voorgaande is enigszins afhankelijk van de diercategorie. Bij gespeende biggen en kraamzeugen is een hogere reductie waarschijnlijk mogelijk, voor dragende zeugen is $60 \%$ reductie al een hele opgave. Implementatie van brongerichte maatregelen zal dus sterk samenhangen met de eisen die gesteld gaan worden (per provincie) aan de verschillende emissies. Worden reducties geëist voor ammoniak van $85 \%$, zoals in Noord Brabant, dan is dit vrijwel onmogelijk alleen te realiseren met brongerichte maatregelen. Worden er ook eisen gesteld aan reductie van methaanemissie, dan zijn luchtwassers in het nadeel aangezien deze geen methaan reduceren.

Hierna wordt een visie gegeven ten aanzien van de implementatie van brongerichte emissiearme technieken met de huidige kennis en regelgeving. In Tabel 6 is een onderverdeling gemaakt van het percentage varkens dat op dit moment is gehuisvest in stallen met brongerichte emissiearme technieken, in stallen met luchtwassers en in stallen met een traditioneel systeem.

Tabel 6 Huidige situatie van het aandeel varkens (\%) in vier groepen stalsystemen (A t/m D) in de vier varkenscategorieën in Nederland (bron: CBS, 2019; Dieren gehuisvest op welk stalsysteem).

\begin{tabular}{|c|c|c|c|c|}
\hline & $\begin{array}{r}\text { A - Brongericht } \\
>60 \% / 70 \%{ }^{1)} \text { NH3- } \\
\text { red. }\end{array}$ & $\begin{array}{r}\text { B - Brongericht } \\
<60 \% / 70 \%{ }^{1)} \text { NH3- } \\
\text { red. }\end{array}$ & C - Luchtwassers & D - Traditioneel \\
\hline Biggen & $31,9 \%$ & $2,8 \%$ & $51,2 \%$ & $14,3 \%$ \\
\hline Kraamzeugen & $18,9 \%$ & $8,9 \%$ & $51,4 \%$ & $20,7 \%$ \\
\hline Dragende zeugen & $0 \%$ & $21 \%$ & $62,8 \%$ & $16 \%$ \\
\hline Vleesvarkens & $5,6 \%$ & $19,5 \%$ & $59 \%$ & $15,8 \%$ \\
\hline
\end{tabular}

1) $>60 \%$ voor dragende zeugen; $>70 \%$ voor de andere categorieën varkens

Om een visie op implementatie van brongerichte emissiearme systemen te geven is het van belang om de huidige situatie te analyseren. Wat is er al gebeurd en wat moet er nog gebeuren? og aan te passen stallen is naast nieuwbouw de potentiële markt voor nieuwe systemen. Het potentieel van de markt bepaalt mede de snelheid van ontwikkeling en implementatie van nieuwe systemen. Daarnaast wordt de snelheid bepaald door het beleid op de implementatie van deze systemen (o.a. subsidie voor ontwikkeling en implementatie).

\section{Traditionele stallen}

Ruwweg 15 - 20\% van de dieren worden op dit moment nog in traditionele stallen gehuisvest. Traditionele stallen zijn nog mogelijk vanwege de mogelijkheid van intern salderen op bedrijfsniveau. Dit betekent dat door een vergaande ammoniakreductie in de ene stal een lagere reductie mogelijk is in een andere stal op hetzelfde bedrijf. Ongeveer de helft van de traditionele stallen zit in de stoppersregeling en zal dus herbestemd of gesloopt moeten worden. De andere helft zal omgebouwd moeten worden naar emissiearme stallen. Het aandeel emissiearme stallen neemt alleen al door deze ontwikkeling toe. De andere helft betreft traditionele stallen op bedrijven die op bedrijfsniveau voldoen 
aan Besluit emissiearme huisvesting (Beh). Door gebruik te maken van intern salderen hebben deze stallen die meer emissie beperken dan de emissie eis en dus een ander stal traditioneel kunnen laten.

\section{Stallen met luchtwassers}

- Vleesvarkens/dragende zeugen

Ongeveer $60 \%$ van het aantal dierplaatsen zijn voorzien van een luchtwasser. Het grootste deel van de luchtwassers zijn geplaatst tussen 2010 en heden. Vanwege levensduur, zal waarschijnlijk minimaal de helft in de komende 10 jaar vervangen moeten worden. Slechts een deel hiervan is geplaatst op verouderde stallen die ook vernieuwd moeten worden. Dit zal maximaal de helft zijn. Afhankelijk van het beleid zal een deel daarvan weer voor een luchtwasser kiezen.

\section{- Biggen/kraamzeugen}

Ongeveer de helft van de huidige stallen voor biggen en kraamzeugen is voorzien van luchtwassers. Deze zijn in het algemeen van meer recentere datum. Daarom is de verwachting dat deze de komende jaren voorzien blijven van luchtwassers.

Stallen met brongerichte maatregelen; ammoniakreductie $<60-70 \%$

Veel van deze stallen zijn tussen 1997 en 2008 gebouwd. Voor de verschillende categoriën varkens gelst het volgende:

\section{- Vleesvarkens/dragende zeugen}

Het betreft ongeveer $20 \%$ van de stallen. Voor een deel zal een aanvullende techniek op het bestaande emissiearme systeem een oplossing zijn. We verwachten dat dit maar een beperkt deel betreft gezien de moeilijkheid om voor deze diercategorieën te voldoen aan de gestelde normen. Een groot deel zal kiezen voor een luchtwasser als aanvullende techniek en in sommige gevallen dan als enige techniek. Het aandeel luchtwassers voor deze diercategorie zal hierdoor toenemen.

\section{- Biggen/Kraamzeugen:}

Het betreft maar een klein deel van de stallen (2-8 \%). Hier zal een groot deel zoeken naar aanvullende technieken om de emissie onder de grenswaardes te krijgen.

Stallen met brongerichte maatregelen; ammoniakreductie > $60-70 \%$

Dit betreft op dit moment alleen kraamzeugen en biggen. Deze voldoen aan de huidige gestelde eisen voor ammoniak. Bij ongewijzigde eisen zal hier zal dus weinig aan gebeuren.

Uit voorgaande analyse blijkt dat bij ongewijzigd beleid (landelijk en/of provinciaal) en ongewijzigde eisen, b.v. ten aanzien van methaan of ten aanzien van het stalklimaat (maximale concentraties ammoniak/fijnstof in de stal), de markt voor implementatie van brongerichte emissiearme technieken nog relatief gering is. Onze inschatting is dat dit ca. $15 \%$ van de dieren betreft.

Brongericht maatregelen zouden daarom gestimuleerd kunnen worden door eisen te stellen aan methaanreductie en eventueel aan het stalklimaat. Varkenshouders zijn zich echter wel zeer bewust van het feit dat een beter stalklimaat (lagere concentraties vervuilende componenten) tot gezondere dieren en een betere productie leiden. Dit betekent dat varkenshouders ook een direct belang hebben bij en gemotiveerd zijn tot het implementeren van brongerichte maatregelen. 


\section{Samenvattende antwoorden op de vragen}

Vraag 1:

Welke bestaande systemen zijn beschikbaar voor een varkenshouder voor directe implementatie voor een integrale brongerichte aanpak van emissies (ammoniak, methaan, geur, fijnstof en endotoxinen), welke leiden tot een vermindering van emissies naar de leefomgeving en een verbetering van het stalklimaat?

Antwoord:

- Voor gespeende biggen zijn verschillende systemen beschikbaar die voldoen aan de minimale eis in de Sbv-regeling voor ammoniakreductie van 70\%. Deze systemen geven naar verwachting ook een significante emissiereductie van methaan en behalve voor de systemen met spoelgoten ook een significante reductie van geur. Deze systemen hebben naar verwachting geen effect op de emissie van fijnstof. Hiervoor is een additionele maatregel nodig.

- Bij kraamzeugen zijn een drietal systemen beschikbaar die voldoen aan de minimale eis in de Sbv-regeling voor ammoniakreductie van 70\%. Deze systemen geven naar verwachting ook een significante emissiereductie van methaan. Voor geur en fijnstof worden geen reducties verwacht.

- Bij dragende zeugen en vleesvarkens is voor elk één systeem beschikbaar die voldoet aan de minimale eis voor ammoniakreductie in de Sbv-regeling (respectievelijk 60\% en $70 \%$ ). Deze systemen geven, naar verwachting, tevens een significante reductie van geur en methaan. Voor fijnstofreductie is een additionele maatregel nodig.

Noot: dat wij de grenzen voor ammoniakreductie gelijk hebben gesteld aan de eisen vanuit de Sbvregeling, betekent niet dat dit de toekomstige normen zullen worden voor ammoniak. Dat besluit moet nog worden genomen.

Vraag 2:

Welke brongerichte maatregelen kunnen gecombineerd worden met een nageschakelde techniek en welke emissiereducties zijn hiermee te behalen?

Antwoord:

Alle brongerichte maatregelen kunnen worden gecombineerd met een nageschakelde techniek. Door brongerichte reductiesystemen te combineren met een luchtwasser kunnen vooral de emissies van ammoniak, geur en fijnstof aanvullend worden gereduceerd. Verwachte reductiepercentages kunnen worden ingeschat aan de hand van de formules die weergegeven zijn in paragraaf 3.1. Door deze combinaties kunnen voor ammoniak zeer hoge reductiepercentages worden gehaald. Brongerichte en nageschakelde technieken zijn vooral aanvullend ten opzichte van elkaar voor methaan en fijnstof. Luchtwassers doen niets aan methaan en brongerichte maatregelen doen vrijwel niets aan fijnstof. Er zijn echter wel een paar additionele maatregelen die puur gericht zijn op fijnstofreductie, die brongericht ook fijnstof aan kunnen pakken.

Vraag 3:

Welke nieuwe brongerichte maatregelen zijn in ontwikkeling en welke bedrijven bieden dit systeem aan?

Antwoord:

De kansrijke initiatieven met brongerichte maatregelen voor emissiereductie worden gekenmerkt door één of een combinatie van onderstaande kenmerken:

- Korte opslagduur van de mest in de stal (dag- of weekontmesting)

- Mestverwijdering via schuiven, spoelen of met een mestband

- Klein emitterend oppervlak

- Goed doorlatende roostervloeren (vooral vleesvarkens) 
- Koelen van de mest

- Verdunnen van de mest (waterkanaal, ammoniak- en geurvrije vloeistof)

- Mestscheiding (schuifsystemen, mestbanden)

Verschillende bedrijven zijn bezig met deze kansrijke initiatieven die mede door de Sbv-regeling verder kunnen worden ontwikkeld en bemeten. Deze testen en metingen op praktijkbedrijven zullen uiteindelijk uitwijzen welke systemen daadwerkelijk kansrijk zijn en verder uitgerold kunnen worden.

Vraag 4:

In welke fase van de innovatiecyclus bevindt dit systeem zich en wanneer is het klaar voor implementatie?

Antwoord:

De verwachting is dat de meeste systemen, waaraan op dit moment bedrijven zijn gekoppeld en waarbij de testfase binnenkort wordt opgestart, voor of rond 2025 zodanig zijn getest en bemeten dat ze, bij succes, in de markt kunnen worden gezet.

Vraag 5:

Wat zijn de potentiële emissiereducties die behaald kunnen worden en welk effect heeft het op de kwaliteit van de stallucht?

Antwoord:

Deze kansrijke nieuwe initiatieven in brongerichte maatregelen reduceren naar verwachting de ammoniak- en methaanemissies met tenminste 70\%. De geuremissie wordt naar verwachting met $50 \%$ of meer gereduceerd. Fijnstof wordt in het algemeen maar zeer beperkt gereduceerd. Hiervoor is een aanvullende brongerichte maatregel nodig (b.v. olienippels of ionisatie van de lucht).

Vraag 6:

Wat zijn de investerings- en jaarkosten voor deze systemen?

Antwoord:

De investeringskosten zijn in het algemeen hoger dan voor de standaard stal met luchtwasser. De jaarkosten zijn naar verwachting vergelijkbaar met deze referentiestal. De jaarkosten zijn de kosten voor afschrijving, rente, onderhoud en variabele exploitatiekosten zoals toevoegmiddelen, afvoer van de toevoegmiddelen, etc.

Vraag 7:

Wat is er nodig aan (nieuwe) kennis om een besluit te kunnen nemen over aanscherping van emissieeisen voor varkens in nieuwe en bestaande stallen?

Antwoord:

Op dit moment zijn al een aantal brongerichte maatregelen beschikbaar die voldoen aan de minimale eisen zoals die gesteld zijn binnen de Sbv-regeling ( $>60-70 \%$ reductie ammoniak, $>50 \%$ reductie methaan, $>25 \%$ reductie geur en fijnstof; voor fijnstofreductie is veelal een additionele maatregel nodig). Enkele brongerichte systemen, die in ontwikkeling zijn, hebben een verwachte ammoniakreductie van 75\%. Wanneer emissie-eisen voor ammoniak worden aangescherpt tot boven de $75 \%$, dan is dit waarschijnlijk alleen mogelijk met nageschakelde technieken of met een combinatie van brongerichte maatregelen en nageschakelde technieken. Nieuwe kennis is vooral nodig ten aanzien van het precieze effect van de (nieuw) ontwikkelde brongerichte maatregelen op de verschillende emissies. In het kader van de Klimaatenvelop en de Sbv-regeling wordt dit inmiddels opgepakt. Gecombineerde effecten van brongerichte maatregelen en nageschakelde technieken zijn ook nog nauwelijks onderzocht.

Vraag 8:

CDM/CBS analyse geeft aan dat er bij veel technieken vragen zijn over de betrouwbaarheid in de praktijk van het rendement. Welke technieken scoren hier beter?

Antwoord:

De emissiereducties zoals weergegeven in de verschillende tabellen in hoofdstuk 3 zijn deels gemeten en voor een ander deel ingeschat. Alle cijfers zijn gebaseerd op een goede werking van het systeem. 
Hoe een bepaald systeem uiteindelijk uitwerkt in de praktijk is sterk afhankelijk van de precieze uitvoering, van het precieze management van het complete systeem en van het noodzakelijke onderhoud van de technische onderdelen van het systeem.

Uit het CBS-rapport (van Bruggen \& Geertjes, 2019) blijkt dat emissiearme systemen voor ammoniak minder efficiënt lijken te zijn dan zou moeten op basis van de afgegeven emissiefactoren. Buiten ontwerpfouten om, zal dit veelal met het management van de systemen te maken hebben. Een goede begeleiding, controle, handhaving en continue monitoring zouden kunnen helpen om emissiereducties op de gewenste niveaus te brengen en te houden. Dit geldt zowel voor de huidige, reeds

geïmplementeerde emissiearme systemen als voor de nieuwe systemen. In de verschillende tabellen in hoofdstuk 3 is een inschatting gemaakt van de betrouwbaarheid/robuustheid van de verschillende systemen. In algemene zin kan worden geconcludeerd dat brongerichte technieken vergelijkbaar of iets beter scoren ten aanzien van betrouwbaarheid/robuustheid dan luchtwassystemen. Echter net als bij luchtwassystemen geldt ook voor de brongerichte systemen dat automatisering van belang is. Zowel automatisering van de gehele regeling van het systeem als de controle op eventuele afwijkingen en minder goed functioneren van het systeem. De data die verzameld wordt bij de monitoring van de verschillende onderdelen van het systeem kan tevens gebruikt worden voor (online) controle door externen.

Het continu monitoren van de ammoniakemissie kan fraudegevoelig zijn. Echter, hiervoor zijn verschillende maatregelen te bedenken om dit te reduceren, b.v. het verzegelen van een meetsysteem om te voorkomen dat deze wordt verhangen en de mogelijkheid om continu de gemeten waarden met de verwachtingswaarden te vergelijken. Bij abrupte veranderingen kan een extra controle uitgevoerd worden. 


\section{Literatuur}

Aarnink, A., de Groot, J., Ogink, N., 2019. Brongerichte maatregelen voor beperking emissies uit bestaande varkensstallen. Wageningen Livestock Research, Wageningen, p. 29.

Bokma-Bakker, M., Hagen, R., Bokma, S., Bremmer, B., Ellen, H., Hopster, H., Neijenhuis, F., Vermeij, I., Weges, J., 2012. Onderzoek naar brandveiligheid voor dieren in veestallen= Study regarding fire safety of barns for farm animals. Wageningen UR Livestock Research.

Cambra-López, M., Hermosilla, T., Lai, H.T., Aarnink, A.J.A., Ogink, N.W.M., 2011. Particulate matter emitted from livestock houses: On-farm source identification and quantification. Transactions of the ASABE 54, 629-642.

CDM, 2020. Advies Commissie van Deskundigen Meststoffenwet (CDM) 'Stikstofverliezen uit mest in stallen en mestopslagen' 18-06-2020. Wageningen University and Research, Wageningen, p. 26.

KWIN-V 2020 - 2021, 2020. Handboek Kwantitatieve Informatie Veehouderij 2020 - 2021 (KWINVeehouderij). Wageningen Livestock Research, Wageningen.

Melse, R.W., Nijeboer, G.M., Ogink, N.W.M., 2018. Evaluatie geurverwijdering door luchtwassystemen bij stallen : deel 2: Steekproef rendement luchtwassers in de praktijk. Wageningen Livestock Research, Wageningen.

Stouthart, F., Melse, R.W., Rensman, D., 2013. Implementatieproject elektronisch monitoren van luchtwassers : rapportage. SRE Milieudienst, Eindhoven.

TNO, Oktober 2019. FACTSHEET EMISSIES EN DEPOSITIE VAN STIKSTOF IN NEDERLAND. TNO, innovation for life, Den Haag.

van Bruggen, C., Geertjes, K., 2019. Stikstofverlies uit dierlijke mest op basis van het verschil in stikstof/fosfaatverhouding bij excretie en bij mestafvoer. CBS.

Winkel, A., Belgers, J., Peters, B., Vermeij, I., Ellen, H., 2012. Ontwikkeling en evaluatie van technieken ter verlaging van stofconcentraties in varkensstallen= Development and evaluation of techniques to mitigate dust concentrations in pig houses. Wageningen UR Livestock Research.

Winkel, A., Wouters, I.M., Aarnink, A.J.A., Heederik, D.J.J., Ogink, N.W.M., 2014. Emissies van endotoxinen uit de veehouderij: een literatuurstudie voor ontwikkeling van een toetsingskader. Wageningen UR Livestock Research, p. 80. 


\section{Bijlage 1 Kosten combi luchtwassysteem}

Onderstaande tabel geeft de investerings- en jaarkosten weer van een combi luchtwassysteem in euro's. De jaarkosten bestaan uit afschrijving, rente, onderhoud en variabele exploitatiekosten zoals energie, 'extra' mestopslag en afzetkosten, kosten van eventuele toevoegmiddelen, etc.

\begin{tabular}{lll} 
Combiwasser & Investering & $\begin{array}{l}\text { Jaarkosten (incl. } \\
\text { afschrijving en variabele } \\
\text { kosten) }\end{array}$ \\
\hline Per biggenplaats & 21 & 5,30 \\
\hline Per kraamzeugenplaats & 200 & 59 \\
\hline Per dragende zeugenplaats & 120 & 33 \\
\hline Per vleesvarkensplaats & 64 & 19,8 \\
\hline
\end{tabular}




\section{Bijlage 2 Uitleg TRL's}

\section{Wat is TRL?}

TRL's, ofwel Technology Readiness Levels zijn ooit door de NASA bedacht om aan te geven in welke fase de ontwikkeling van een nieuwe technologie zit. Voor veel Europese en nationale subsidies wordt dit model gebruikt om te duiden voor welke fase van een innovatietraject een subsidie bedoeld is (https://www.snn.nl/kennisbank/trl-niveaus-uitgelegd).

We onderscheiden 9 TRL's. Hoe hoger het level, hoe dichter bij het op de markt brengen van de innovatie. De 9 levels zijn weer gegroepeerd in vier overkoepelende fasen, namelijk:

- De ontdekkingsfase (TRL 1,2 \& 3)

- De ontwikkelingsfase (TRL 4,5 en 6)

- $\quad$ De demonstratiefase (TRL $7 \& 8$ )

- De toepassingsfase (TRL 9)

\section{De volgende 9 TRL levels kunnen worden onderscheiden:}

\section{Level 1: Fundamenteel onderzoek}

Je doet onderzoek naar het innovatieve idee en de basisprincipes van de innovatie. Je bent hierbij bezig met fundamenteel onderzoek en deskresearch.

\section{Level 2: Toegepast onderzoek}

Je hebt de basisprincipes onderzocht en gaat nu bezig met de formulering van het technologisch concept en de praktische toepassingen. In deze fase ben je vooral bezig met experimenteel en/of analytisch onderzoek.

\section{Level 3: Proof of concept}

Je onderzoekt de toepasbaarheid van het concept op experimentele basis (experimenteel proof of concept). Je toetst en valideert hypotheses over verschillende componenten van het concept.

\section{Level 4: Implementatie en test prototype}

Je gaat de Proof-of-concept van jouw innovatie op labschaal testen. Het design, de ontwikkeling en het testen van technologische componenten vinden plaats in een labomgeving. Je integreert technische basiscomponenten met elkaar om de werking te garanderen. Een prototype dat je in deze fase ontwikkelt, kost relatief weinig geld en tijd om te ontwikkelen en is daarmee nog ver verwijderd van een definitief product, proces of dienst.

\section{Level 5: Validatie prototype}

Je onderzoekt de werking van het technologisch concept in een relevante omgeving. Dit is de eerste stap in de demonstratie van de technologie. Een prototype dat je in deze fase ontwikkelt, kost relatief veel tijd en geld en is niet ver verwijderd van het uiteindelijke product of systeem.

\section{Level 6: Demonstratie prototype in testomgeving}

Je gaat het concept uitgebreid testen en demonstreren in een relevante testomgeving, Deze testomgeving lijkt op een operationele omgeving, bijvoorbeeld in een pilot plant. Het testen vindt plaats na de technische validatie in een relevante (pilot) omgeving. Het concept geeft

\section{Level 7: Demonstratie prototype in operationele omgeving}

Je gaat het concept testen en demonstreren in een gebruikersomgeving om werking in een operationele omgeving te bewijzen. De demonstratie van het concept in een praktijkomgeving levert je nieuwe inzichten op voor de definitieve markttoepassing van jouw innovatie.

\section{Level 8: Product/ dienst is compleet en operationeel}

In deze fase krijgt jouw innovatie zijn definitieve vorm. Je hebt de technologische werking getest en het is bewezen dat het voldoet aan gestelde verwachtingen, kwalificaties en normen (certificering). Daarnaast bepaal je de financiële kaders voor (massa)productie en lancering.

\section{Level 9: Marktintroductie product/dienst/procedé}

Jouw innovatie is technisch en commercieel gereed; productierijp en klaar voor lancering in de gewenste marktomgeving. Nu het totale ontwikkelingsproces is afgerond is de volgende stap het commercieel wegzetten van een product bij de gewenste doelgroep in de juiste markt. 

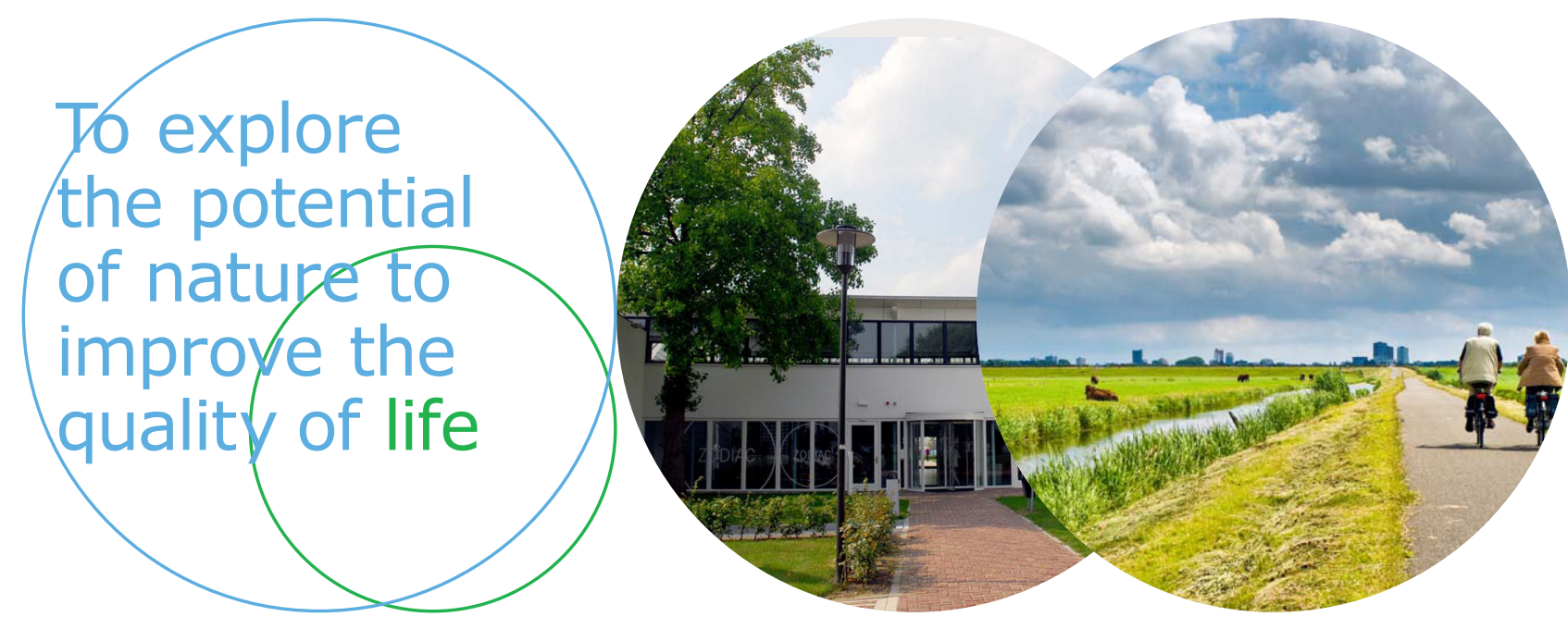

Wageningen Livestock Research Postbus 338

$6700 \mathrm{AH}$ Wageningen

T 0317483953

E info.livestockresearch@wur.nl www.wur.nl/livestock-research
Wageningen Livestock Research ontwikkelt kennis voor een zorgvuldige en renderende veehouderij, vertaalt deze naar praktijkgerichte oplossingen en innovaties, en zorgt voor doorstroming van deze kennis. Onze wetenschappelijke kennis op het gebied van veehouderijsystemen en van voeding, genetica, welzijn en milieu-impact van landbouwhuisdieren integreren we, samen met onze klanten, tot veehouderijconcepten voor de $21 \mathrm{e}$ eeuw.

De missie van Wageningen University \& Research is 'To explore the potential of nature to improve the quality of life'. Binnen Wageningen University \& Research bundelen 9 gespecialiseerde onderzoeksinstituten van Stichting Wageningen Research en Wageningen University hun krachten om bij te dragen aan de oplossing van belangrijke vragen in het domein van gezonde voeding en leefomgeving. Met ongeveer 30 vestigingen, 6.500 medewerkers en 10.000 studenten behoort Wageningen University \& Research wereldwijd tot de aansprekende kennisinstellingen binnen haar domein. De integrale benadering van de vraagstukken en de samenwerking tussen verschillende disciplines vormen het hart van de unieke Wageningen aanpak. 